\title{
A APLICAÇÃO DO PRINCÍPIO DA CAPACIDADE CONTRIBUTIVA NA TRIBUTAÇÃO SOBRE O PATRIMÔNIO DESTINADO À HABITAÇÃO E A CONCRETIZAÇÃO DO DIREITO FUNDAMENTAL À MORADIA
}

Larissa Firmo da Silva

\section{INTRODUÇÃO}

A Constituição da República Federativa do Brasil de 1988 (CRFB/1988), inaugurando o título VI “Da tributação e do orçamento", determina no $\$ 1^{\circ}$ do seu art. 145 que "sempre que possível, os impostos terão caráter pessoal e serão graduados segundo a capacidade econômica do contribuinte (...)". Dessa forma, consagra o princípio da capacidade contributiva, que, por sua vez, estabelece que a tributação deve ocorrer em conformidade com o signo presuntivo de riqueza revelado por cada indivíduo.

Sendo assim, inequívoca a constatação de que, no campo tributário, o referido princípio mostra-se essencial para a consagração da isonomia em seu sentido material, sendo fator essencial, portanto, para a operacionalização da Justiça Tributária.

Nesse sentido, é possível notar que a tributação dentro dos moldes da capacidade contributiva estabelece a necessidade de a cobrança estar pautada em critérios que, embora permitam que aqueles com situação econômica privilegiada contribuam mais que os desfavorecidos economicamente, também determinam que todo contribuinte tenha o direito de ser tributado adequadamente. Ou seja, não há que se cogitar que a tributação atinja a esfera do mínimo existencial dos indivíduos (limite mínimo da capacidade contributiva) ou seja tão excessiva que acabe por atingir níveis confiscatórios (limite máximo da capacidade contributiva).

Ocorre que, se por um lado, nos impostos pessoais - v.g. Imposto de Renda a aplicação do princípio ora em comento é aceita de forma praticamente unânime, 
no que tange aos impostos reais, especificamente os impostos sobre o patrimônio destinado à moradia (Imposto sobre Propriedade Territorial Urbana - IPTU e Imposto Territorial Rural - ITR), o posicionamento dominante tem-se encontrado - equivocadamente - em sentido oposto. Nesses impostos, a utilização do princípio da capacidade contributiva acaba sofrendo restrições, em virtude do fato de eles incidirem diretamente sobre o patrimônio imobilizado (renda estática) e respectivas características, e não, sobre a pessoa do contribuinte em si, desconsiderando-se, por completo, que a manutenção da renda estática é feita pela renda dinâmica dos indivíduos.

Ressalte-se que, ao limitar o tema do presente trabalho à análise do IPTU e do ITR, busca-se destacar a necessidade de a capacidade contributiva ser considerada na tributação destes impostos para que, então, o direito fundamental à moradia seja preservado, evitando-se, com isso, que a cobrança mal calibrada desses impostos ocasione a perda do bem imóvel envolvido.

Dessa forma, no decorrer do presente trabalho, será contínua a busca por instrumentos capazes de assegurar a máxima observância da capacidade contributiva nesses impostos e o consequente respeito ao direito fundamental à moradia dos contribuintes, compatibilizando-se, por certo, com a incontestável necessidade de o Estado arrecadar impostos para a satisfação das necessidades coletivas. Para isso, mostrou-se essencial a análise, sobretudo, do texto constitucional, do CTN, de leis municipais, bem como de jurisprudências, que auxiliaram na demonstração de que o que aqui se propõe é plenamente compatível com o Ordenamento Jurídico pátrio.

A fim de melhor orientar a leitura, válido salientar que o primeiro capítulo desta monografia expõe as principais considerações sobre o princípio da capacidade contributiva e sua aplicação no sistema tributário nacional. O segundo capítulo, por sua vez, analisa a importância do direito à moradia e a necessária compatibilização desse direito fundamental com o Poder de Tributar do Estado. E, finalizando o trabalho, o terceiro capítulo dispõe sobre algumas formas de aperfeiçoamento da capacidade contributiva na tributação sobre o patrimônio destinado à moradia.

\section{A APLICAÇÃO DO PRINCíPIO DA CAPACIDADE CONTRIBUTIVA NO SISTEMA TRIBUTÁRIO BRASILEIRO}

\subsection{Arrecadação tributária e Justiça Fiscal}

É inequívoco que a cobrança de tributos é essencial para o cumprimento da função arrecadatória do Estado e, consequentemente, essencial à realização de des- 
pesas imprescindíveis à consecução do bem comum. Sendo assim, não restam dúvidas de que a arrecadação de tributos constitui-se em conduta persecutória do interesse público.

No entanto, não se deve considerar que a referida função arrecadatória pode ser exercida de toda e qualquer forma, sendo importante considerar também que o Direito Tributário deve atender aos aspectos de justiça tributária, afinal, como leciona Klaus Tipke e Douglas Yamashita ${ }^{1}$, "O legislador, que observa a teoria do Direito Tributário justo, demonstra moral tributária. O cidadão, que paga impostos segundo leis tributárias justas, demonstra moral tributária ou age moralmente em matéria tributária”.

Justiça é um valor almejado, em regra, por toda sociedade, entretanto, apesar de ser um dos direitos mais fundamentais, a amplitude e, muitas vezes, a indeterminação de seu conceito, podem conduzir a conclusões arbitrárias dotadas de subjetivismos em excesso, de modo que a cada indivíduo ou grupo de indivíduos corresponda uma significação diferente e, não raramente, contraditória do conceito - aberto - de justiça.

Dessa forma, faz-se essencial a busca por alternativas que impeçam a existência de contradição em um direito tão fundamental a todos os indivíduos. Para isso, Klaus Tipke e Douglas Yamashita ${ }^{2}$, baseando-se em privilegiada doutrina de Chaïm Perelman, dispõem sobre a necessidade da aplicação dos princípios para que se alcance um Direito efetivamente justo, afastando, com isso, as lacunas do Ordenamento Jurídico. Assim, estar-se-ia diante de medidas uniformes capazes de proporcionar tratamento igualitário a todos abrangidos pelo conteúdo aberto dos princípios aplicáveis, afastando-se, com isso, de um regime arbitrário.

No entanto, é necessário reconhecer que a mera aplicação de quaisquer princípios, por si só, não é suficiente à consecução de um direito efetivamente justo em seu aspecto material, restringindo-se à obtenção da justiça formal, que, por sua vez, mostrou-se, ao longo dos anos, insuficiente para a concretização plena da isonomia.

A isonomia em seu sentido material pressupóe a necessidade de que pessoas diferentes sejam tratadas de forma diferenciada, entretanto, os critérios de comparação, que, consequentemente, estabelecem as diferenças entre os indivíduos, não

TIPKE, Klaus; YAMASHITA, Douglas. Justiça fiscal e princípio da capacidade contributiva. São Paulo: Malheiros, 2002, p. 15.

2 Ibidem, p. 19. 
•• Tributação, direitos fundamentais e desenvolvimento

podem ser instituídos a bel prazer do aplicador da norma, haja vista que, para a efetiva ocorrência de justiça, mostra-se necessária a adequação do critério à "natureza das realidades comparadas" ${ }^{3}$. Observe-se:

Posto que a aplicação do princípio da igualdade consiste em concluir o pensamento de regras da disciplina jurídica pertinente, é indispensável que o examinador de ofensas ao princípio da igualdade conheça as regras que fundamentam o sistema. O que no caso concreto é igual ou desigual se deixa constatar não abstrata ou universalmente, mas apenas com o auxílio de regras adequadas ao objeto ${ }^{4}$.

Dessa feita, é fundamental que os princípios a serem aplicados sejam adequados ao fim que se pretende alcançar, ou seja, é de suma importância que sejam aplicados princípios e critérios constitucionalmente válidos, de modo que as diferenças de tratamentos só possam ser admitidas se justificadas pela ocorrência de outro princípio justo com valor igual ou superior, sob pena de estar-se diante de um sistema arbitrário e de um tratamento discriminatório ou concessor de privilégios injustificáveis ${ }^{5}$.

Inegável que o Direito possui uma diversidade muito ampla de áreas e que a essas correspondem determinadas peculiaridades. Sendo assim, não se pode admitir que apenas um princípio baste ao objetivo comum de se alcançar uma aplicação justa do direito como um todo, sendo necessário, portanto, que a cada seara do direito corresponda um critério adequado à matéria e à finalidade específica que se pretende alcançar.

Nessa toada, válido destacar as conclusões obtidas por Klaus Tipke e Douglas Yamashita ${ }^{6}$ :

O conceito indeterminado da justiça é concretizado num primeiro nível como se segue: justiça por meio de tratamento isonômico; tratamento isonômico segundo um critério adequado à matéria; justiça social - tributação socialmente justa com base num princípio adequado à matéria, que somente pode ser sacrificado por princípios de mesmo valor.

Diante disso, resta claro que o Direito Tributário deve operar de forma a garantir uma aplicação justa dos diplomas integrantes de seu regime jurídico, afinal, leis fiscais sem qualquer relação com justiça constituem meramente um "tumulto tributário", e não, um Direito Tributário7. Assim, há que se perquirir, também,

\footnotetext{
Ibidem, p. 55.

Ibidem, p. 55-56.

Ibidem, p. 20.

Ibidem, p. 22.

7 Ibidem, p. 28.
} 
para o referido ramo jurídico, um critério principiológico adequado à consecução de seu principal fim, qual seja, o "de obter, de modo justo, os recursos necessários para o orçamento de cada ente federativo" ${ }^{8}$, compatibilizando-o, outrossim, com a conservação do mínimo existencial de cada um.

Dentre os princípios que poderiam ser cogitados para concretizar, no campo do Direito Tributário, a isonomia, e, consequentemente, a justiça, pertinente tecer comentários sobre os que se seguem: princípio do imposto "per capita” e princípio da equivalência'.

Segundo a ideia do princípio do imposto "per capita”, a cobrança da tributação ocorreria sobre cada pessoa individualmente, desconsiderando-se, integralmente, as diferenças inerentes aos indivíduos, tais como a renda que cada um aufere, bem como, as despesas necessárias à sobrevivência e consequente possibilidade de contribuir para as despesas estatais. Assim, os mais abastados financeiramente contribuiriam na mesma medida dos que teriam menor disponibilidade de renda.

No que tange ao princípio da equivalência, esse preceitua que o pagamento de tributos se daria como retribuição aos serviços prestados, de modo que o indivíduo ou grupo de indivíduos que mais se beneficiasse dos serviços públicos, teria que arcar, em maior quantidade, com o ônus gerado pela tributação. Estabelecer-se-ia uma situação similar às taxas, entretanto, com maior grau de prejudicialidade aos hipossuficientes, que, por necessitarem mais dos referidos serviços, teriam que arcar em maior parte com a tributação, mesmo sem ter disponibilidade de renda suficiente para tal.

É inegável que tais princípios não se mostram adequados, uma vez que definem verdadeira situação de injustiça fiscal com flagrante ofensa ao princípio da isonomia. Com isso, o princípio da capacidade contributiva vem à tona para prevalecer em face dos anteriormente referidos, haja vista que se mostrou, de fato, o mais adequado à consecução da chamada justiça fiscal, como a seguir será melhor explicitado.

\subsection{A tributação segundo os ditames da capacidade contributiva}

A Constituição da República Federativa do Brasil de 1988 preceitua em seu art. $145, \$ 1^{\mathrm{o}}$, o que se segue ${ }^{10}$ :

Ibidem, p. 39.

Ibidem, p. 28-29.

10 BRASIL. Constituição (1988). Constituição da República Federativa do Brasil. Brasília, Distrito Federal: Senado, 1988. Disponível em: <http://www.planalto.gov.br/ccivil_03/constituicao/constituicaocompilado.htm>. Acesso em: 5 jan. 2015. 
•• Tributação, direitos fundamentais e desenvolvimento

Art. $145(\ldots)$

$\$ 1^{\circ}$ Sempre que possível, os impostos terão caráter pessoal e serão graduados segundo a capacidade econômica do contribuinte, facultado à administração tributária, especialmente para conferir efetividade a esses objetivos, identificar, respeitados os direitos individuais e nos termos da lei, o patrimônio, os rendimentos e as atividades econômicas do contribuinte.

Indubitavelmente, o texto constitucional vigente consagrou o princípio da capacidade contributiva como critério de comparação válido para a consagração do princípio da isonomia em âmbito tributário e não haveria conclusão mais lógica a se chegar, pois, tratando-se os tributos de prestações pecuniárias compulsórias, como conceitua o art. $3^{\circ}$ do Código Tributário Nacional - CTN -, a capacidade econômica, que se configura como o demonstrativo da realidade econômica do contribuinte, mostra-se intrinsecamente ligada a eles, demonstrando, consequentemente, ser o mais adequado critério de comparação ${ }^{11}$.

No entanto, inobstante a consagração constitucional da capacidade contributiva enquanto princípio mais adequado a comparar as diferenças entre os contribuintes, a expressão "sempre que possível", utilizada no artigo constitucional supramencionado, faz com que a eficácia da isonomia segundo a capacidade contributiva seja posta à prova, haja vista que há entendimentos segundo os quais a expressão utilizada indica uma observância nem sempre obrigatória do referido princípio.

Ocorre que interpretaçóes como essa mostram-se equivocadas, uma vez que o dispositivo em nada se relaciona com uma restrição de eficácia, mas, ao contrário, demonstra a maximização dessa, uma vez que apenas expressa que sua aplicação pode ocorrer de diferentes formas e em vários graus, enfatizando, ainda, que exceções são admitidas, contanto que estejam plenamente justificadas e que o princípio da proporcionalidade esteja sendo observado ${ }^{12}$, tal como na hipótese de impostos com finalidade extrafiscal.

Nesse sentido, destaca-se a conclusão feita pelo renomado autor Luciano Amaro, segundo o qual “(...) a possibilidade referida no texto abre campo precisamente para a conjugação com outras técnicas tributárias (como a extrafiscalidade), que precisam ser utilizadas em harmonia com o princípio ali estatuído" (grifo original $)^{13}$.

TIPKE, Klaus; YAMASHITA, Douglas. Op. cit., p. 56.

12 Ibidem, p. 54.

13 AMARO, Luciano. Direito tributário brasileiro. 17. ed. São Paulo: Saraiva, 2011, p. 163. 
Superada essa discussão, o princípio da capacidade contributiva, enquanto critério apto à realização da justiça fiscal, possui como núcleo central o entendimento no sentido de que a tributação apenas poderá ser imputada àqueles que possuem condições de contribuir com as despesas do Estado, ou seja, àqueles que denotam algum signo presuntivo de riqueza, pois "onde não houver riqueza é inútil instituir imposto, do mesmo modo que em terra seca não adianta abrir poço à busca de água" ${ }^{14}$.

Ademais, importante também considerar que uma tributação apenas tem como fundamento o princípio da capacidade contributiva na medida em que não se atinge o mínimo existencial do indivíduo. Com isso, não há que se cogitar que a colaboração com as despesas do Estado, por meio do pagamento dos tributos, ocorra em prejuízo das necessidades vitais do indivíduo e de sua família, pois, nessa hipótese, não haveria demonstração de capacidade contributiva e, consequentemente, não haveria renda disponível para ser atingida.

Dessa forma, constata-se que a amplitude do princípio da capacidade contributiva vai além de caracterizá-la como um dos aspectos da isonomia, haja vista que também garante aos contribuintes detentores de capacidade contributiva que esta não seja extrapolada por uma tributação abusiva e excessiva.

Ainda, em que a pese o inequívoco entendimento acerca da adequação da capacidade contributiva como critério capaz de tornar a arrecadação de tributos mais justa, essencial destacar elementos, inerentes ao referido princípio, capazes de impedir sua aplicação distorcida e que, consequentemente, impedem a exigência de tributos em desacordo com os moldes da justiça fiscal.

Nessa toada, conforme asseveram Klaus Tipke e Douglas Yamashita ${ }^{15}$, a aplicação da capacidade contributiva é cabível a todos os tributos com finalidade arrecadatória, independentemente de atingirem a renda dinâmica ou estática do indivíduo. É essencial, entretanto, que se perquira a sua renda real, haja vista que eventual imputação de um tributo com base em presunções, tais como em relação à renda que o homem médio auferiria, em regra, poderia implicar grave violação à isonomia.

Ademais, importante também o destaque feito pelos autores mencionados anteriormente no que tange à caracterização do princípio da capacidade contributiva

Ibidem, p. 167.

15 TIPKE, Klaus; YAMASHITA, Douglas. Op. cit., p. 32. 
•• Tributação, direitos fundamentais e desenvolvimento

como princípio de individualidade, que, por sua vez, não se confunde com princípio da pessoalidade - que mais a frente será explicitado. Frise-se que a capacidade contributiva deve ser aferida individualmente, não sendo adequado, em regra, a sua aferição com base na capacidade de contribuir com as despesas do Estado de um determinado grupo que eventualmente o indivíduo esteja inserido, pois “o fato de pertencer a um determinado grupo nada expressa sobre a capacidade contributiva individual"16.

Por fim, há que se enfatizar que o mandamento constitucional constante na segunda parte do $\$ 1^{\circ}$, do art. 145 , ao dispor sobre a necessidade de respeito a outros direitos fundamentais, bem como ao já previsto em lei, estabelece que a identificação da capacidade contributiva, garantia não só do contribuinte, mas também do próprio fisco, não pode ocorrer de qualquer forma, devendo ser aplicada de forma harmônica com outros princípios e direitos, bem como em conformidade com os limites estabelecidos em lei, sob pena de restar caracterizada flagrante inconstitucionalidade.

Válido, então, destacar o seguinte ensinamento de Luciano Amaro ${ }^{17}$ :

(...) A autoridade tem, portanto, o dever de fiscalizar, mas, para isso, deve respeitar o devido processo legal e observar os direitos do indivíduo. Não pode, portanto, agir fora do que a lei previamente tenha autorizado (princípio genérico da legalidade); nem se lhe permite divulgar os dados que apure sobre o patrimônio, os rendimentos e as atividades do contribuinte, pois isso feriria o direito à privacidade; nem se admite que, para investigar o contribuinte, utilize métodos desumanos ou degradantes; não pode também pretender a obtenção de informações que não sejam necessárias à investigação fiscal etc.

\subsection{A capacidade contributiva e os impostos pessoais}

Valendo-se novamente do texto do art. $145, \$ 1^{\circ}$, da CFRB/1988, é importante notar que a expressão "sempre que possível" não se refere apenas ao princípio da capacidade contributiva, mas também à exigência de graduação pessoal dos impostos.

É inegável a importância de se considerar as características pessoais do contribuinte quando da cobrança de tributos, sob pena de restar violado o princípio da isonomia, haja vista que, conforme já demonstrado, este exige que sejam direciona-

Ibidem, p. 32.

AMARO, Luciano. Op. cit., p. 167. 
dos aos contribuintes tratamentos diferenciados e adequados às condições específicas de cada um. Deve-se ressaltar que não se quer, com isso, que os impostos sejam tantos quantos forem os contribuintes, mas, sim, que seja adotado um

(...) modelo de incidência de tal sorte que, na sua aplicação concreta, tais ou quais características dos indivíduos (número de dependentes, volume de despesas médicas etc.) sejam levadas em consideração para efeito de quantificação do monte do imposto devido em cada situação concreta ${ }^{18}$.

Dessa feita, segundo a classificação didática comumente repassada, tem-se que imposto pessoal, em contraposição ao imposto real, é aquele mensurado de acordo com as condições pessoais dos indivíduos, tais como estado civil, idade, existência de filhos etc., sendo que o maior exemplo desse imposto é o Imposto de Renda.

Não há dúvidas da íntima relação existente entre os impostos pessoais e o princípio da capacidade contributiva, pois, na medida em que esse princípio busca uma identificação sobre a efetiva possibilidade de o contribuinte continuar gerando riqueza, mesmo com o patrimônio diminuído por força do pagamento de débitos tributários ${ }^{19}$, a consideração das características pessoais de cada sujeito passivo é essencial. Assim, inevitável constatar que a personalização do imposto, característica inerente aos impostos pessoais, "pode ser vista como umas das faces da capacidade contributiva (...)"20.

Pelo exposto, forçoso reconhecer a necessidade de aplicação plena da capacidade contributiva aos impostos pessoais, uma vez que esses pressupōem a averiguação efetiva da realidade econômica dos contribuintes para que, então, seja possível a ocorrência da tributação, ou, ainda, nas palavras de Bernardo Ribeiro Moraes apud Abel Henrique Ferreira ${ }^{21}$

(...) São, pois, os impostos que recaem sobre todos os elementos relativos à capacidade contributiva do sujeito passivo, levando em conta condições individuais do contribuinte, tais como idade, estado civil, grau de parentesco, domicílio, filhos, vulto da renda ou patrimônio, existência de dívidas passivas etc.

18 Ibidem, p. 164.

19 ATALIBA, Geraldo e GIARDINO, Cléber apud AMARO, Luciano. Ibidem, p. 162.

20 Ibidem, p. 162 e 164.

21 FERREIRA, Abel Henrique. O princípio da capacidade contributiva frente aos tributos vinculados e aos impostos reais e indiretos. Disponível em: <http://www.fesdt.org.br/artigos/06.pdf> Acesso em: 5 jan. 2015, p. 15. 
•• Tributação, direitos fundamentais e desenvolvimento

\subsection{A capacidade contributiva e os impostos reais}

Ultrapassando a discussão acerca da possibilidade de o comando constitucional do $\$ 1^{\circ}$ do art. 145 tornar obrigatória a observância do princípio da capacidade contributiva em todos os tributos ou apenas em relação aos impostos ${ }^{22}$, fato é que com relação a essa espécie tributária, o dispositivo é claro. Assim, todos os impostos, independentemente de se referirem à renda dinâmica ou à renda estática do contribuinte, devem "ser graduados segundo a capacidade econômica do contribuinte", conforme define o mencionado dispositivo constitucional.

Com relação aos impostos pessoais, como já visto, não há maiores dificuldades. Entretanto, quando se atém à tributação sob a forma de impostos reais, a concretização da capacidade contributiva torna-se mais complexa, haja vista que em tais tipos de impostos o respectivo cálculo tende a ser feito com base apenas no objeto imediato a ser tributado, ou seja, a incidência do imposto recai sobre certos bens do contribuinte, desconsiderando, por completo, as características pessoais deste. Válido, então, ressaltar as considerações feitas por Bernardo Ribeiro Moraes apud Abel Henrique Ferreira ao conceituar imposto real ${ }^{23}$ :

(...) Os impostos reais gravam o contribuinte tendo em vista apenas a matéria tributável, segundo seus caracteres objetivos específicos, independentemente das condiçôes econômicas, jurídicas, pessoais ou de família relativas ao contribuinte. (...) São, pois impostos que gravam manifestações isoladas de capacidade contributiva, v.g., a posse de um bem que é tributada sem se levar em conta a situação individual do contribuinte.

No entanto, em que pese a maior dificuldade de aplicação do referido princípio aos impostos reais, imperioso constatar que a sua inaplicabilidade implicaria ofensa ao mandamento constitucional disposto no art. 145, $\$ 1^{\circ}$. Além disso, configuraria clara situação de injustiça fiscal, pois como é de notório conhecimento de todos, o princípio da capacidade contributiva é "postulado universal de

Para fins de informação, destaca-se o posicionamento do STF no sentido de admitir a aplicação do princípio da capacidade contributiva a outras espécies tributárias, além do imposto, conforme pode ser observado no julgamento da ADI n. 948/GO e no RE n. 232.393. Disponível em: $<$ http://www.stf.jus.br/portal/processo/verProcessoAndamento.asp?incidente=1572111> e $<$ http://www.stf.jus.br/portal/processo/verProcessoAndamento.asp?incidente=1719435>. Acesso em: 24 set. 2015.

23 FERREIRA, Abel Henrique. Op. cit., p. 15. 
justiça fiscal”, o que significa dizer que, "não se pode, na criação de impostos reais (como soem ser os impostos indiretos), estabelecer critérios de quantificação do gravame em termos que ofendam a presumível capacidade econômica do contribuinte $(. . .)^{\prime 24}$.

Corroborando com este entendimento, válido destacar que a classificação entre impostos reais e pessoais é contestada por muitos autores, como é o caso de Augusto Becker, tendo em vista que "a tributação recairá sempre sobre um contribuinte, ou seja, sobre uma pessoa, não existindo, portanto, a referida distinção" 25 . Registre-se que o bem, objeto imediato da tributação, não é capaz de se auto-sustentar e, assim, por óbvio, quem arca com o ônus referente ao pagamento do imposto real é o contribuinte, por meio de sua renda dinâmica.

Isso posto, deve-se atentar que, inseridos na categoria de impostos reais estão os impostos de incidência indireta, como o IPI (Imposto sobre Produtos Industrializados) e o ICMS (Imposto sobre a Circulação de Mercadoria e Serviços), e os de incidência direta, hipótese da tributação sobre o patrimônio. No presente trabalho, será objeto de análise apenas este último e, mais precisamente, os impostos incidentes sobre o patrimônio destinado à habitação, caso do IPTU (Imposto Predial e Territorial Urbano) e do ITR (Imposto Territorial Rural). Note-se que, embora haja resistência em se aplicar a capacidade contributiva em todos os impostos reais, merece especial atenção o caso do IPTU e do ITR, uma vez que os referidos impostos possuem uma estreita relação com o direito à moradia, que se configura direito fundamental garantido constitucionalmente e que será visto adiante.

Logo, considerando a exigência de respeito aos direitos fundamentais disposta no art. $145, \$ 1^{\circ}$, da $C R F B / 1988$, a inaplicabilidade da capacidade contributiva aos impostos sobre o patrimônio destinado à habitação, de forma eficaz e plena, além de soar inconstitucional, acabar por limitar ou, até mesmo, extinguir o direito de os contribuintes terem um local para habitação, como se verá no decorrer do presente trabalho.

AMARO, Luciano. Direito tributário brasileiro, op. cit., p. 164.

25 PAOLIELLO, Patrícia Brandão. O princípio da capacidade contributiva. Disponível em: <http://jus.com.br/artigos/4138/o-principio-da-capacidade-contributiva> Acesso em: 6 jan. 2015. 
•• Tributação, direitos fundamentais e desenvolvimento

\section{A TRIBUTAÇÃO SOBRE O PATRIMÔNIO DESTINADO À HABITAÇÃO E A CONCRETIZAÇÃO DO DIREITO CONSTITUCIONAL À MORADIA}

\subsection{A proteção ao direito à moradia até o advento da "Constituição Cidadã"}

\subsubsection{Considerações gerais}

Conforme se pode observar da leitura do artigo $6^{\circ}$, caput, da Constituição da República Federativa do Brasil, após redação determinada pela Emenda Constitucional n. 26, de 2000, o direito à moradia foi alçado à categoria de direito social constitucionalmente garantido.

Não obstante tal constatação sob a ótica formal - ou seja, considerando, meramente o capítulo em que foi inserido a proteção ao direito à moradia - deve-se considerar que o referido direito não se restringe à classificação como direito social, haja vista configurar-se como um direito garantidor e gerador de outros direitos fundamentais à subsistência de todos os indivíduos, tais como o direito à segurança, à saúde, ao trabalho, dentre outros. Dessa forma, negar o caráter fundamental deste direito mostra-se uma tarefa praticamente impossível, pois "não há como dissociar a moradia da personalidade do indivíduo, pois além de servir de abrigo, a ela estão atrelados outros significantes, como a vida e a dignidade humana"26.

Nesse sentido, também se encontra o elemento basilar da já referida EC 26/2000, responsável por incluir o direito à moradia no texto constitucional. A idealização desta Emenda Constitucional ocorreu em meio a um contexto, a princípio, contraditório, uma vez que, embora fosse patente a lacuna na Carta Política brasileira, no que se refere à consagração da proteção expressa ao direito à moradia, o Brasil foi convidado a assumir a relatoria de uma das partes da Agenda do Habitat da Conferência Habitat II - convocada pela Organização das Nações Unidas (ONU) - que se propunha a discutir o tema relacionado ao "direito à moradia". Tais circunstâncias podem ser observadas no seguinte trecho da justificativa da referida $\mathrm{EC}^{27}$ :

26 CARLI, Ana Alice de. Bem de família do fiador e o direito humano fundamental à moradia. Rio de Janeiro: Lumen Juris, 2009, p. 9.

27 BRASIL. Poder Legislativo. Comissão de Constituição e justiça e de redação. Diário do Senado Federal, Brasília, DF, 19.06.1996, p. 10244-10245. Disponível em: <http:/www.stf.jus.br/ 
A aplicação do princípio da capacidade contributiva na tributação...

(...) Coube-lhe, assim, a difícil tarefa de justificar, frente a países como Japão, Estados Unidos e Coreia (que se posicionam contra a inclusão desse termo na Agenda), a urgente necessidade de se reconhecer a moradia como um direito social.

A participação ativa brasileira em tão importante evento, de caráter mundial, coloca-nos em posição delicada, principalmente quando se verifica, em meio de uma situação eminentemente crítica das áreas urbanas brasileiras, uma lacuna na própria Constituição Federal, que não reconhece a moradia como um direito real, como a saúde, o lazer, o trabalho etc. Mais delicada, ainda, fica a situação do Brasil quando, sabedores da realização da Conferência, os "sem-teto" de todo o País, já bastante organizados, ameaçam "pipocar ocupaçôes de terrenos" na periferia das grandes cidades - conforme se lê nos mais renomados jornais do País.

As atuais condiçôes de moradia de milhões de brasileiros chegam a ser deprimentes e configuram verdadeira "chaga social" para grande parte das metrópoles do país. Faz-se, portanto, urgente que se dê início a um processo de reconhecimento da moradia como célula básica, a partir da qual se desenvolvem os demais direitos do cidadão, já reconhecidos por nossa Carta Magna: a saúde, o trabalho, a segurança, o lazer, entre outros. Sem a moradia, o indivíduo perde a identidade indispensável ao desenvolvimento de suas atividades, enquanto ente social e produtivo se empobrece e se marginaliza. Com ele, se empobrece, invariavelmente, a Nação. (Grifou-se).

Diante dessas considerações, imperiosa a constatação de que a inclusão do direito à moradia no texto constitucional foi responsável por inserir o Brasil no cenário mundial como um dos precursores da ideia de que a moradia é direito fundamental e que, portanto, deve ser objeto de atuação de todo Estado, que tem o dever de garantir tal direito a todos os indivíduos, independentemente de raça, gênero, religião etc.

Outrossim, válido destacar que, embora, atualmente, o Estado brasileiro perceba que a importância de se garantir o direito à moradia está intrinsecamente relacionada com a dignidade humana de todos os indivíduos, nem sempre tal fato justificou a proteção estatal a esse direito, haja vista que, sobretudo nos períodos em que vigoravam regimes autoritários, a dignidade da pessoa humana era claramente desprezada. Assim, considerando que no decorrer da história brasileira houve diferentes razões que justificaram a proteção do direito à moradia, conveniente fracionar o estudo dessas justificativas em três fases distintas, quais sejam: a de saúde pública; a econômica; e a atual, que considera o direito à moradia intrínseco à vida digna dos indivíduos, fases que serão abordadas a seguir.

arquivo/biblioteca/pec/EmendasConstitucionais/EC26/Senado/EC026_sen_18061996_ini. pdf $>$. Acesso em: 11 out. 2014. 
•• Tributação, direitos fundamentais e desenvolvimento

\subsubsection{O direito à moradia como questão de saúde pública}

Em um primeiro momento, o Estado brasileiro percebeu que garantir esse direito e viabilizar instrumentos que permitissem seu exercício de forma digna relacionava-se não apenas com o interesse particular de cada um, mas principalmente com o interesse público, sendo essencial, inclusive, para manutenção da ordem pública e do equilíbrio social.

Com o crescimento populacional decorrente do êxodo rural, tornou-se evidente a questão sobre a saúde pública. Esse fator fez com que houvesse também o crescimento desordenado de casas sem qualquer infraestrutura, comumente financiadas por grupos, que viram no mercado imobiliário o melhor investimento para auferir lucros no nível máximo. Com isso, a construção de casas precárias, "com material barato e de qualidade duvidosa", tornou-se o chamariz para a chamada "exploração imobiliária"28. Inegável que a ampliação desses tipos de construções, sem qualquer estrutura sanitária, por exemplo, tornou-se a grande preocupação do Poder Público, haja vista ser este o cenário ideal para proliferação de doenças e possíveis surtos epidêmicos que, por sua vez, poderiam gerar também graves reflexos na economia ${ }^{29}$.

Diante disso, com o objetivo de controlar a referida expansão desordenada e, assim, evitar a ocorrência de maiores prejuízos à sociedade, coube a adoção de medidas de controle, dentre às quais, preponderaram as que se seguem, conforme ensinamento de Nabil Bonduki apud Ana Alice De Carli" : "controle sanitário das habitações; edição de legislação e códigos de posturas; e a participação direta em obras de saneamento das baixadas, urbanização da área central e implantação de água e esgoto".

No entanto, na primeira fase, em que pese uma preocupação embrionária do Estado com relação ao direito fundamental em comento, as políticas estatais de contenção das moradias precárias não se mostravam eficientes, haja vista que a destruição desses tipos de imóveis implicaria o surgimento de outro grande problema, qual seja, a ocorrência de milhares de pessoas sem abrigo, o que, por sua vez, contribuiria para a continuidade da exploração imobiliária largamente realizada. Nesse sentido, válido destacar o seguinte:

CARLI, Ana Alice de. Bem de família do fiador e o direito humano fundamental à moradia. Rio de Janeiro: Lumen Juris, 2009, p. 14.

29 Ibidem, p. 15.

30 Ibidem, p. 15. 
A aplicação do princípio da capacidade contributiva na tributação...

(...) Nesse paradoxo entre norma e contingência, os proprietários-locadores se aproveitavam da situação e continuavam construindo casas de baixo custo e desprovidas de infraestrutura: de fato, havia dois cenários distintos: de um lado, o homem com poucos recursos que ansiava por um teto para morar e, de outro, o capitalista que buscava precipuamente auferir lucro com o empreendimento imobiliário, sem se preocupar com possíveis sequelas decorrentes de más construçōes. ${ }^{31}$

\subsubsection{O direito à moradia como forma de estímulo ao desenvolvimento econômico do Brasil}

Percebe-se que, já na primeira fase, o fator econômico influenciou a atuação estatal frente à preocupação com a precariedade das moradias, pois os iminentes surtos epidêmicos poderiam causar séria desconfiança no Brasil frente ao cenário mundial. No entanto, apenas com o governo de Getúlio Vargas, a partir de 1930, e a intensa e oportunista preocupação com os trabalhadores, o fator econômico tornou-se determinante para justificar as políticas públicas de melhoria das condições para exercício do direito à moradia.

Durante esse período, os trabalhadores assumiram, ao menos na teoria, um papel de destaque na sociedade, pois foram considerados o público-alvo do governo Vargas, que buscou incutir nos trabalhadores o sentimento de valorização, de modo que, como forma de estímulo a uma produção cada vez mais eficiente, a classe operária era constantemente denominada de "principal base de sustentação política"32.

Nesse sentido, como forma de concretizar o objetivo estatal de gerar estímulo à produção dos obreiros e, consequentemente, ao desenvolvimento econômico do país, além de o Poder Público ter subsidiado várias conquistas afetas diretamente à seara trabalhista, tais como limitação da jornada de trabalho, foram assegurados diversos direitos no intuito de proporcionar maior bem-estar à classe operária e, assim, estimulá-la a produzir melhor.

Dentre esses direitos, destaca-se o direito à moradia ou, mais que isso, o exercício desse direito em uma habitação própria - o que até então estava distante da realidade da maioria esmagadora da população - e que, por óbvio, não foi estimulado tendo por único escopo a melhoria da condição de vida do trabalhador como um fim em sim mesmo, afinal, "(...)O pensamento dominante era o de que o tra-

31 Ibidem, p. 15.

32 BONDUKI, Nabil apud CARLI, Ana Alice de. Op. cit., p. 16. 
•• Tributação, direitos fundamentais e desenvolvimento

balhador, ao ter acesso à própria casa, se sentiria progredindo e, por consequência, teria maior estímulo para o trabalho" ${ }^{33}$.

Ademais, válido se atentar que, inobstante a adoção de políticas governamentais de incentivo à moradia, a solução para a grave crise habitacional ficou distante de ser alcançada, tendo em vista que, mesmo com a adoção dessas medidas, a intensa demanda por um local para o exercício da moradia contrapunha-se à baixa oferta de habitações, sobretudo com valores compatíveis aos baixos salários dos trabalhadores. Com isso, o fenômeno da autoconstrução, aliado à clandestinidade dos imóveis não contida pelo Poder Público, tornou-se a melhor alternativa para superar o grande desafio de se obter uma habitação, sendo essencial, no entanto, ter-se em mente os seguintes apontamentos:

a omissão do Poder Público na expansão dos loteamentos clandestinos fazia parte de uma estratégia para facilitar a construção da casa pelo próprio morador que, embora não tivesse sido planejada, foi se definindo na prática como um modo de viabilizar uma solução habitacional 'popular', barata, segregada, compatível com a baixa remuneração dos trabalhadores e que, ainda, lhes desse a sensação, falsa ou verdadeira, de realizar o sonho de se tornarem proprietários $(\ldots)^{34}$.

\subsubsection{O direito à moradia e a materialização do direito fundamental à dignidade humana (art. $6^{\circ} \mathrm{CRFB} / 1988$ )}

Com o advento da Constituição da República Federativa do Brasil de 1988 (CRFB/1988), principal símbolo do processo de redemocratização brasileira, a dignidade da pessoa humana tornou-se um dos fundamentos do Estado Democrático de Direito brasileiro, conforme disposição do art. 10 da CRFB/1988, em seu inciso III. Semelhantemente ao que ocorreu na Alemanha, Espanha e Portugal, com o fim dos respectivos regimes autoritários, no Brasil também "a tortura e toda sorte de desrespeito à pessoa humana praticadas sob o regime militar [durante mais de duas décadas] levaram o constituinte brasileiro a incluir a dignidade da pessoa humana" 35 como um de seus fundamentos.

Dessa forma, enquanto fundamento do Estado Democrático de Direito brasileiro, o princípio da dignidade da pessoa humana legitima a existência desse e,

Ibidem, p. 16.

34 BONDUKI, Nabil apud CARLI, Ana Alice de. Op. cit., p. 19.

35 SILVA, José Afonso da. Comentário contextual à Constituição. 8. ed. São Paulo: Malheiros, 2012, p. 39. 
com isso, onde não houver o respeito ao referido princípio fundamental constitucional, não haverá também a concretização do Estado Democrático de Direito pátrio $^{36}$.

Diante disso, faz-se essencial compreender o verdadeiro significado da garantia de proporcionar a todos uma existência digna, merecendo destaque as seguintes palavras de José Afonso da Silva: “(...)vê-se que a dignidade é atributo intrínseco, da essência, da pessoa humana, único ser que compreende um valor interno, superior a qualquer preço, que não admite substituição equivalente. Assim, a dignidade entranha e se confunde com a própria natureza do ser humano" ${ }^{37}$.

Com isso, tratando-se de atributo intrínseco a todos os indivíduos, não há que se cogitar sobre sua renúncia ou sobre uma espécie de graduação de importância e respeito a depender das condutas praticadas por cada um, não sendo admissível, portanto, “afirmar - como Santo Tomás de Aquino para justificar a pena de morte - que o homem, ao delinquir, se aparta da ordem da razão e, portanto decai da dignidade humana e se rebaixa em certo modo à condição de besta (grifo original)"38.

Ademais, válido ressaltar que a concretização do referido atributo intrínseco à pessoa humana exige a presença de requisitos mínimos de existência que garantam a todos o direito a uma vida digna. Ainda, importante atentar-se que tais requisitos não se restringem à esfera individual do sujeito, sendo essencial, de igual modo, a coexistência de fatores que garantam o bem-estar da família, assim como, um bom relacionamento com outros membros da sociedade, concluindo, então, que a realização dos direitos pessoais não é suficiente à caracterização da vida digna, devendo-se considerar imprescindível que também haja o respeito aos direitos sociais, econômicos e culturais.

Dessa forma, imperioso destacar lição de Gomes Canotilho e Vital Moreira apud José Afonso da Silva ${ }^{39}$ :

(...) Concebido como referência constitucional unificadora de todos os direitos fundamentais, o conceito de dignidade da pessoa humana obriga a uma densificação valorativa que tenha em conta o seu amplo sentido normativo-constitucional e não uma qualquer ideia apriorística do homem, não podendo reduzir-se o sentido da dignidade humana à defesa dos direitos pessoais tradicionais, esquecendo-a nos casos de

\footnotetext{
36 Ibidem, p. 37.

37 Ibidem, p. 40.

38 Ibidem, p. 40.

39 Ibidem, p. 40.
} 
•• Tributação, direitos fundamentais e desenvolvimento

direitos sociais, ou invocá-la para construir 'teoria do núcleo da personalidade' individual, ignorando-a quando se trate de direitos econômicos, sociais e culturais.

Nesse ponto, com a devida vênia, em consonância com o tema do presente trabalho, merecem destaque, especificamente, os comentários a respeito da relação entre a dignidade da pessoa humana e o direito social - e fundamental, como já visto - à moradia.

Quando se fala em moradia ou habitação, em regra, tem-se em mente um local onde o indivíduo permaneça, por tempo indeterminado, para ali constituir uma família e satisfazer suas necessidades básicas - tais como dormir e comer - ou, ainda, pode-se considerar, que ter uma moradia significa ter um refúgio de tudo aquilo que não diz respeito à sua privacidade.

Diante disso, forçoso reconhecer que o direito à moradia não deve ser considerado direito meramente social, como já visto, uma vez que se constitui como requisito essencial para a concretização de outros direitos, sendo, ainda, conforme preleciona Ana Alice de Carli ${ }^{40}$, "um dos corolários da dignidade da pessoa humana, esta como norma propulsora de todos os sistemas sociais (...)", afinal, não se pode imaginar que um indivíduo viva dignamente sem um local, próprio ou não, para permanecer habitualmente e satisfazer suas necessidades privadas.

Outrossim, admitir possível uma vida digna sem um local para morar significa clara violação aos objetivos fundamentais da República Federativa do Brasil previstos no art. $3^{\circ}$ da Carta Política, destacando-se os incisos que preveem a erradicação da pobreza e da marginalização e a promoção do bem de $\operatorname{todos}^{41}$, tendo em vista que, além de uma moradia digna ser pressuposto para realização do bem de todos, “(...) não há marginalização maior do que não se ter um teto para si e para a família" ${ }^{\prime 2}$.

Com isso, chega-se à conclusão de que o dever do Estado, ao garantir a todos o direito à moradia, não se restringe a, meramente, proporcionar um local para habitação, mas, principalmente, proporcionar um local de moradia onde o indivíduo e sua família possam satisfazer suas necessidades básicas de forma digna.

CARLI, Ana Alice de. Op. cit., p. 10.

41 CRFB/1988: Art. 30 Constituem objetivos fundamentais da República Federativa do Brasil: (...) III - erradicar a pobreza e a marginalização e reduzir as desigualdades sociais e regionais; IV - promover o bem de todos, sem preconceitos de origem, raça, sexo, cor, idade e quaisquer outras formas de discriminação.

42 SILVA, José Afonso da. Op. cit., p. 190. 
Tal constatação, inobstante não estar expressa no texto constitucional, como ocorre nas Constituições portuguesa e espanhola, à luz do princípio da dignidade humana - que como já visto é um dos fundamentos do Estado Democrático de Direito brasileiro -, é ínsito ao ordenamento jurídico brasileiro, uma vez que, conforme lição José Afonso da Silva ${ }^{43}$.

(...) Se nossa Constituição prevê, como um princípio fundamental, a dignidade da pessoa humana (art. $\left.1^{\circ}, \mathrm{III}\right)$, assim como direito à intimidade e à privacidade (art. $5^{\circ}$, $\mathrm{X}$ ), e que a casa é um asilo inviolável (art. $5^{\circ}, \mathrm{XI}$ ), então tudo isso envolve, necessariamente, o direito à moradia. Não fosse assim, seria um direito empobrecido.

Ainda, complementa o mencionado autor ao tecer comentários sobre a eficácia do referido direito:

Esse [o direito à moradia] é daqueles direitos que têm duas faces: uma negativa e uma positiva. A primeira significa que o cidadão não pode ser privado de uma moradia, nem impedido de conseguir uma, no que importa abstenção do Estado e de terceiros. A segunda que é a nota principal do direito à moradia consiste no direito de obter uma moradia digna e adequada, revelando-se como um direito positivo de caráter prestacional, porque legitima a pretensão do seu titular à realização do direito por via de ação positiva do Estado (...) (grifos originais) ${ }^{44}$.

Pelo exposto, imprescindível considerar que, inexistindo, efetivamente, o exercício do direito à moradia, depara-se com inequívoca afronta ao princípio da dignidade humana, que, por sua vez, é um dos requisitos que torna possível a existência do Estado Democrático de Direito. Assim, qualquer conduta de particulares ou do Estado no sentido de impedir ou limitar o exercício do direito à habitação pelo indivíduo, tais como a cobrança de tributos excessivamente onerosos em dissonância com a capacidade contributiva do contribuinte, configura inegável violação a preceito constitucional, como será visto no decorrer do trabalho.

\subsection{O poder de tributar e a necessária compatibilização com os direitos fundamentais}

Dispõe o art. $3^{\circ}$ do Código Tributário Nacional brasileiro (Lei n. 5.172/1966) ${ }^{45}$ : "Tributo é toda prestação pecuniária compulsória, em moeda ou cujo valor nela se

43 Ibidem, p. 190.

44 Ibidem, p. 190.

45 BRASIL. Lei 5.172 de 25 de outubro de 1966 (Código Tributário Nacional). Brasília, Distrito Federal: Senado, 2002. Disponível em: <http://www.planalto.gov.br/ccivil_03/leis/15172. htm>. Acesso em: 5 set. 2014. 
•• Tributação, direitos fundamentais e desenvolvimento

possa exprimir, que não constitua sanção de ato ilícito, instituída em lei e cobrada mediante atividade administrativa plenamente vinculada”.

Abstraindo-se do conceito de tributo os demais elementos - que, não obstante serem essenciais para o referido conceito, não serão objeto deste tópico - destaca-se o fato de ele ser compulsório, bem como ter que ser instituído por lei, uma vez que, não fossem essas características, tal espécie de prestação pecuniária poderia ser confundida com tantas outras.

Desta feita, deve-se atentar para o fato de que a compulsoriedade dos tributos, aliada à necessidade de sua instituição ser por meio de lei, pode ser considerada como um fator determinante para que o poder de instituí-los tenha sido exclusivamente direcionado aos entes políticos integrantes da República Federativa do Brasil - conforme art. 145 da CRFB/88 - pois trata-se de um elemento que impõe uma obrigação aos particulares independentemente de suas manifestaçóes de vontade. Nesse sentido, merece destaque lição de Luiz Eduardo Shoueri:

O tributo não é pago por um ato de vontade, mas em estrito cumprimento de uma determinação legal. Já se disse, jocosamente, que se o imposto fosse voluntário, então ele mudaria de nome: de “imposto" para "voluntário". É nesse sentido que se deve compreender a natureza compulsória do tributo: não se deve questionar seu mérito, uma vez surgida a obrigação. Ao contribuinte não resta outra opção, senão cumprir sua obrigação e o Fisco, por outro lado, deve recebê-la ${ }^{46}$.

Diante das referidas características, torna-se inequívoca a impossibilidade de se cogitar acerca da delegação deste poder a quem quer que seja, tendo em vista que, além de constituir-se como profunda limitação à liberdade dos indivíduos, em última análise, "é manifestação do poder constituinte, que o outorga, pela Constituição, [art. 145 CRFB/88] e nos limites nela estabelecidos, às entidades estatais”ł7. Sendo assim, faz-se indispensável, primeiramente, perquirir o motivo pelo qual o Poder Constituinte, expressão máxima da soberania do povo, entendeu necessária a autorização constitucional para a cobrança de tributos.

Forçoso reconhecer que, apesar de implicar limitação à liberdade dos indivíduos, a tributação é uma forma essencial de salvaguardar as necessidades dos membros da sociedade, sobretudo em um país como o Brasil, onde ainda impera "imensa

46 SCHOUERI, Luís Eduardo. Direito tributário. 2. ed. São Paulo: Saraiva, 2012, ISBN 978-8502-16120-7, item 4.3 - capítulo III, e-book.

47 SILVA, José Afonso da. Op. cit., p. 666. 
desigualdade, má distribuição de renda e elevado índice de pobreza" ${ }^{48}$, circunstâncias essas que fazem com que parcela significativa da população não tenha condições de, por si só, satisfazer suas necessidades vitais, necessitando, então, que o Estado proporcione a eles recursos que os permitam sobreviver.

Dessa forma, indubitavelmente, o Estado necessita das receitas geradas por meio da cobrança de tributos para que, assim, seja possível não apenas a sua conservação como máquina administrativa pública, mas, sobretudo, para garantir a todos a proteção dos direitos fundamentais. Nesse sentido, válido destacar posicionamento de Sacha Calmon Navarro Coêlho ${ }^{49}$ :

O poder de tributar, modernamente, é campo predileto de labor constituinte. A uma, porque o exercício da tributação é fundamental aos interesses do Estado, tanto para auferir as receitas necessárias à realização de seus fins, sempre crescentes, quanto para utilizar o tributo como instrumento extrafiscal, técnica em que o Estado intervencionista é pródigo. A duas, porque tamanho poder há de ser disciplinado e contido em prol da segurança dos cidadãos.

Com isso, pode-se perceber que a tributação possui um aspecto dúplice, tendo em vista que, ao mesmo tempo em que caracteriza um poder do Estado com aptidão para limitar a liberdade dos indivíduos - direito fundamental garantido constitucionalmente no caput do art. $5^{\circ}$-, é também um dever fundamental do contribuinte, necessário à garantia dos seus direitos fundamentais assegurados constitucionalmente. Nesse sentido, válido destacar o seguinte:

É verdade que a receita tributária é condicionada à existência da economia privada e também à garantia dos direitos dos particulares. Por outro lado, o contrário também é verdade, pois é a receita obtida com a tributação que possibilita a existência e manutenção do direito à propriedade, ao patrimônio privado, à livre iniciativa etc..$^{50}$.

Diante disso, como forma de justificar o dever de pagar tributos dos contribuintes, válido invocar o disposto no caput e no inciso I do art. $3^{\circ}$ da CRFB/1988: "Constituem objetivos fundamentais da República Federativa do Brasil: I - construir

48 NOGUEIRA, André Murilo Parente; ROSSO, Maria Izabel Souza. O Estado fiscal e o poder de tributar. Revista Jurídica da Presidência da República, Brasília, v. 9, n. 84, abr./maio 2007. Disponível em: <http://www.planalto.gov.br/ccivil_03/revista/Rev_84/Artigos/PDF/AndreMurilo_rev84.pdf>. Acesso em: 20 jan. 2015, p. 198.

49 COÊLHO, Sacha Calmon Navarro. Curso de direito tributário brasileiro. 7. ed. Rio de Janeiro: Forense, 2004, p. 39.

50 PROCHALSKI, Daniel. Solidariedade social e tributação. Disponível em: <http://sisnet.aduaneiras.com.br/lex/doutrinas/arquivos/270607a.pdf>. Acesso em: 24 jan. 2015, p. 8. 
•• Tributação, direitos fundamentais e desenvolvimento

uma sociedade livre, justa e solidária (...)”. Embora tal dispositivo não esteja inserido no capítulo dedicado à regulamentação do Sistema Tributário Nacional, não há dúvidas de que tal objetivo, sobretudo no que tange à construção de uma sociedade solidária - que será objeto de estudo neste tópico - é de observância obrigatória em todas as searas do ordenamento jurídico brasileiro.

Com isso, depreende-se que não apenas o dever de pagar impostos tem como corolário o cumprimento do referido objetivo constitucional. O próprio poder de tributar não mais se justifica, exclusivamente, em razão de disposição legal que prevê a tributação como forma possível de geração de receitas, mas principalmente em virtude de a tributação ser considerada como um instrumento de auxílio na construção de uma sociedade solidária. Assim, “(...) na ponderação de valores constitucionais, o peso do valor 'arrecadação' (por estar circunscrito ao âmbito tributário) é menor do que o peso do valor 'solidariedade social' (por ser um objetivo fundamental)" ${ }^{51}$.

Ainda, necessário acrescentar que, considerando o novo fundamento precípuo da tributação, o poder de tributar tornou-se "poder juridicizado funcionalmente justificado”, o que significa dizer que apenas terá legitimidade

na medida em que, além de atender aos requisitos formais e materiais de sua emanação, os preceitos por ele editados estejam no plano concreto efetivamente direcionados à busca da construção da sociedade livre, justa e solidária ou, pelo menos, que não neguem o valor solidariedade social nem prejudiquem, dificultem ou discriminem as formas sociais de cooperaçãa ${ }^{52}$.

Dessa feita, imperioso constatar que a chamada solidariedade fiscal deve pautar a atuação dos dois polos da relação jurídica tributária - contribuinte e fisco pois a construção de uma sociedade solidária mostra-se essencial para a sustentação do Estado brasileiro. Inequivocamente, tal fato é imprescindível aos interesses do contribuinte, uma vez que, como já visto, o Estado demonstra ser o maior responsável pela proteção aos direitos individuais, tais como livre iniciativa, propriedade privada etc.

Assim, mostra-se essencial uma atuação concorrente do fisco e dos contribuintes no sentido de colaborarem para realização de valores e direitos garantidos

\footnotetext{
51 ROSSO, Paulo Sérgio. Tributação e solidariedade no Estado brasileiro. Revista Eletrônica da $O A B$. Disponível em: <http://www.oab.org.br/editora/revista/revista_07/anexos/ tributacao_e_solidariedade.pdf>. Acesso em: 25 jan. 2015, p. 10.

52 Ibidem, p. 7.
} 
A aplicação do princípio da capacidade contributiva na tributação...

aos integrantes da sociedade. Válido, então, destacar os comentários feitos por Paulo Sérgio Rosso ${ }^{53}$ referentes à defesa sobre a necessidade de tributação:

É a noção, amparada no raciocínio lógico, de que mesmo aquele que paga tributos sem receber o correspondente em benefícios estatais, tem interesse na manutenção do Estado, pois não haveria espaço para a propriedade privada numa sociedade instável, onde imperasse apenas a força bruta.

Outrossim, tomando-se como ponto de partida o fato de que a atividade estatal consistente em arrecadar tributos não é mero fim em si mesmo, mas sim uma forma de concretização de valores e direitos fundamentais, válido reiterar que, em virtude do abismo social e econômico existente entre os membros da população brasileira, o exercício dos direitos fundamentais, por óbvio, resta prejudicado àqueles com condições financeiras precárias. Com isso, conforme já visto, ao Estado cabe assumir o papel de extinguir ou, ao menos, amenizar as barreiras impeditivas do exercício dos referidos direitos.

Dessa forma, a redistribuição alcançada por meio da tributação emerge como um meio, em tese eficiente, de corrigir, ainda que minimamente, os males causados pela profunda desigualdade social existente no Brasil, uma vez que possibilita ao Estado reutilizar, estrategicamente, o montante acumulado em decorrência dos tributos arrecadados e, assim, garantir o seu próprio desenvolvimento, bem como das classes da sociedade ${ }^{54}$. Com isso, segue-se a lógica básica da redistribuição, que é direcionar recursos excedentes dos contribuintes para os não contribuintes ${ }^{55}$, ou seja, para aqueles que não revelem, ou revelem de maneira insatisfatória, capacidade contributiva.

Note-se, destarte, que os contribuintes nem sempre serão o alvo dos benefícios gerados pelo montante auferido por meio da tributação - o que se denomina referibilidade - haja vista que tal circunstância não se constitui como elemento essencial à cobrança de tributos, salvo nas hipóteses de tributos vinculados, o que se justifica até mesmo em razão do caráter redistributivo da tributação, que fará com que o produto da arrecadação tributária seja direcionado àqueles que efetivamente necessitem dos recursos públicos para a garantia de uma vida digna.

Com isso, é necessário excluir a noção de comutatividade como justificativa para o cumprimento do dever fundamental de pagar impostos, sendo, ao contrário,

\section{Ibidem, p. 7.}

54 FAEDDA, Barbara apud ROSSO, Paulo Sérgio. Op. cit., p. 3.

55 PROCHALSKI, Daniel. Op. cit., p. 3. 
-. Tributação, direitos fundamentais e desenvolvimento

"um dever individual de solidariedade social, pela simples razão de pertencer a uma comunidade" $"$.

Nesse sentido, válido a seguinte reflexão:

a partir do momento em que o estado tributa manifestações de riqueza dos mais abastados para depois redistribuí-la a quem não detém os recursos suficientes a fim de manter uma vida digna, não está apenas baseado no seu poder soberano, de império e coercitivo, mas está fundado em valores maiores que antes apenas lastreavam o campo da moral para fazerem emergir, atualmente, novos fundamentos ao direito, em especial, ao tributário ${ }^{57}$

No entanto, em que pese o fato de o caráter redistributivo da tributação exsurgir como um dos principais objetivos dessa, necessário compreender que, mesmo com este escopo, o poder de tributar não pode ser feito de toda e qualquer maneira, devendo sofrer limitação para que, assim, esteja garantido o respeito aos direitos fundamentais do contribuinte. Surgem, então, as denominadas "limitaçôes ao poder de tributar", cuja definição é sintetizada com mérito por Luciano Amaro ${ }^{58}$ :

(...) as chamadas 'limitaçôes do poder de tributar" integram o conjunto de traços que demarcam o campo, o modo, a forma e a intensidade de atuação do poder de tributar (ou seja, do poder, que emana da Constituição, de os entes políticos criarem tributos) (...) O que fazem, pois, essas limitaçôes é demarcar, delimitar, fixar fronteiras ou limites ao exercício do poder de tributar (...) (grifos originais)

Ressalte-se que, além do disposto acerca das referidas limitações em normas infraconstitucionais, a própria CRFB/1988 tratou de dispor sobre as denominadas limitações ao poder de tributar, que, ora traduzidas sob a forma de princípios orientadores da atividade estatal - tais como o da legalidade, anterioridade e da capacidade contributiva -, ora assumindo a forma de regras de delimitação de competência e aplicação de imunidades, têm por fim resguardar o contribuinte, proporcionando-lhe "uma posição jurídica constitucionalmente privilegiada diante do ente tributante, titular da potestade tributária" ${ }^{59}$, de modo a pacificar

Ibidem, p. 4.

57 MOTTA, Marianna Martini. Do poder de tributar ao dever fundamental de pagar impostos: a via da efetivação dos direitos sociais. Disponível em: <http://www.ambito-juridico.com.br/ site/index.php?n_link=revista_artigos_leitura\&artigo_id=2252>. Acesso em: 24 jan. 2015.

58 AMARO, Luciano. Op. cit., p. 129.

59 PISANI, Carolina Dorneles. O princípio da capacidade contributiva e os limites ao poder de tributar: um caminho à concretização da justiça fiscal. Disponível em: <http://www.anfip.org. br/publicacoes/20120726211721_Carolina-Dorneles-Pisani-II-Concurso-de-Monografias- 
a relação entre o fisco e o contribuinte, que, a princípio, representaria interesses contrapostos $^{60}$.

Destaca-se, ainda, que tamanha preocupação em proporcionar o equilíbrio de forças entre o contribuinte e o fisco resultou na previsão de um rol aberto de limitações ao exercício do poder de tributar. Assim, a CRFB/1988, em seu art. 150, além de direcionar o referido poder no sentido de coibir seu exercício em desacordo com princípios ali elencados, dispõe também sobre a impossibilidade de violação a outros direitos e garantias fundamentais, in verbis: "Art. 150. Sem prejuizo de outras garantias asseguradas ao contribuinte, é vedado à Uniāo, aos Estados, ao Distrito Federal e aos Municípios (...)" (grifou-se) ${ }^{61}$.

Imprescindível considerar, ademais, que as referidas limitações, além de representarem restrições ao poder de instituir e majorar tributos, demonstram, sobretudo, a necessidade de compatibilização com os direitos fundamentais dos contribuintes, que devem ficar protegidos de violaçôes injustificadas. Diz-se violação injustificada, uma vez que, inevitavelmente, haverá mitigação, especialmente do direito à liberdade, já que esta, no que tange ao pagamento de tributos, estará restrita à opção pela prática ou não do fato gerador, que uma vez ocorrido, ensejará o pagamento obrigatório do tributo - salvo na hipótese de não incidência ou dispensa do pagamento.

Como não se pretende, com o presente trabalho, aprofundar os estudos sobre as limitações ao poder de tributar, a pormenorização das referidas limitações acabaria por desvirtuar o seu objetivo, motivo pelo qual, data venia, os comentários serão restritos à análise da importância da capacidade contributiva - assim como outros princípios que o tangenciem - frente aos impostos incidentes sobre o patrimônio destinado à habitação, como será visto no tópico a seguir.

\subsection{Capacidade de manutenção da renda estática pela renda dinâmica e a pessoalização dos tributos}

Como já visto, a tributação poderá incidir sobre a renda dinâmica ou renda estática dos indivíduos. Diz-se renda dinâmica aquela auferida constantemente e

1-Lugar_28-04-2011_monografia_carolina_dorneles_pisani_2011.pdf >. Acesso em: 6 set. 2014, p. 15.

60 Ibidem, p. 14.

${ }^{61}$ BRASIL. Constituição (1988). Constituição da República Federativa do Brasil. Brasília, Distrito Federal: Senado, 1988. Disponível em: <http://www.planalto.gov.br/ccivil_03/constituicao/ConstituicaoCompilado.htm>. Acesso em: 20 set. 2015. 
•• Tributação, direitos fundamentais e desenvolvimento

que se mostra apta à aquisição e conservação dos diversos bens pertencentes aos indivíduos. Por outro lado, renda estática constitui-se como sendo aquela consubstanciada no patrimônio imobilizado dos indivíduos e que, por sua vez, nem sempre demonstra capacidade de auto-sustento, fazendo com que tanto sua aquisição quanto sua manutenção relacionem-se diretamente com a utilização da renda dinâmica pelo indivíduo.

Desta forma, conforme já mencionado, tem-se que inobstante a tributação recair ora sobre a renda dinâmica - valor auferido continuamente sob a forma, v.g., de salário - e ora sobre a renda estática - patrimônio imobilizado - não resta dúvidas de que, em regra, será a pessoa do contribuinte que irá suportar os ônus relacionados à conservação dos seus bens, inclusive no que tange ao pagamento dos tributos incidentes sobre o patrimônio, e fará isso por meio de sua renda dinâmica.

De acordo com o artigo $3^{\circ}$ do Código Tributário Nacional (CTN), o tributo é uma prestação pecuniária que deve ser paga em moeda ou cujo valor nela se possa exprimir, fazendo com que seja iniciada a discussão acerca da possibilidade ou não de pagamento dos tributos por meio de bens. $\mathrm{O}$ art. 156 do referido diploma legal, após advento da Lei Complementar 104/2001, passou a prever, em seu inciso XI, a possibilidade de extinção do crédito tributário por meio de dação em pagamento de bens imóveis, ou seja, tornou-se possível que a extinção do referido crédito ocorresse com a entrega, pelo devedor ao credor, de coisa diversa da anteriormente acordada, exigindo-se para tanto, que a coisa entregue fosse um bem imóvel.

No entanto, em que pese o ordenamento jurídico pátrio admitir a extinção do crédito tributário pela entrega de coisa - imóvel - diversa à qual o contribuinte se obrigou perante o fisco, não há que se cogitar que tal modalidade extintiva ocorra a bel prazer do devedor, uma vez que são elementos essenciais a esse instituto a concordância do credor, bem como sua ocorrência de acordo com os ditames de lei específica, sob pena de restar prejudicada sua constitucionalidade. Válido destacar, então, lição de Carlos Roberto Gonçalves ${ }^{62}$ :

A dação em pagamento é um acordo de vontades entre credor e devedor, por meio do qual o primeiro concorda em receber do segundo, para exonerá-lo da dívida, prestação diversa da que lhe é devida.

Em regra, o credor não é obrigado a receber outra coisa, ainda que mais valiosa (CC, art. 313). Já no direito romano se dizia: aliud pro alio, invito creditore, solvi non potest

62 GONÇALVES, Carlos Roberto. Direito civil brasileiro. 11. ed. São Paulo: Saraiva, 2014, v. 2: Teoria geral das obrigaçôes, item 1 - capítulo V, e-book. 
(uma coisa por outra, contra a vontade do credor, não pode ser solvida). No entanto, se aceitar a oferta de uma coisa por outra, caracterizada estará a dação em pagamento (...)" (grifos originais).

Assim, considerando não ser faculdade do devedor entregar coisa imóvel diversa do valor do tributo devido em moeda, mesmo na hipótese de o bem imóvel ser de valor superior ao devido, inevitável constatar que o pagamento é a forma natural de extinção do crédito tributário, haja vista que representa a concretização da obrigação contraída pelo contribuinte quando da prática do fato gerador.

Note-se que o pagamento apenas consubstancia-se com a "entrega, ao credor, a quantia em dinheiro que corresponde ao objeto da obrigação" "63, ou seja, especificamente na seara do Direito Tributário, o pagamento só ocorrerá quando houver a entrega do valor em dinheiro correspondente ao valor do tributo devido, independentemente deste ser incidente sobre a renda ou sobre o patrimônio, fato que demonstra a incontestável correlação existente entre a renda dinâmica e renda estática do indivíduo ou, ainda, mais precisamente, a profunda dependência desta em relação àquela.

Diante disso, imperiosa a constatação de que mesmo na hipótese de tributação incidente sobre o patrimônio, haverá sempre a necessidade de utilização da renda dinâmica do indivíduo, de modo que esta será determinante para a conservação de seu patrimônio. Assim, considerando a existência da referida dependência, mostra-se insuficiente a mera análise das características do bem tributado, sobretudo quando este se refere ao patrimônio destinado à habitação, sendo essencial também a averiguação de características pessoais dos indivíduos, uma vez que, do contrário, a capacidade contributiva desses poderia restar prejudicada.

\subsection{A tributação sobre o patrimônio destinado à habitação e a preservação do mínimo vital como forma de concretização da capacidade contributiva}

Resta claro o fato de que a tributação só poderá incidir sobre manifestações que denotem algum signo presuntivo de riqueza, haja vista não ser possível o exercício do poder de tributar em face daqueles incapazes de demonstrar capacidade contributiva ainda que temporariamente. Isso porque, como já se sabe, os indivíduos

63 AMARO, Luciano. Op. cit., p. 417. 
•• Tributação, direitos fundamentais e desenvolvimento

nessa situação não possuiriam condições de contribuir para com as despesas do Estado sem prejuízo do próprio sustento e o de sua família.

Assim, pode-se compreender que o entendimento acima descrito retrata a situação consubstanciada na impossibilidade de se tributar o mínimo existencial dos membros da sociedade, uma vez que, conforme lição de Regina Helena Costa ${ }^{64}$, a capacidade contributiva somente restará demonstrada quando se referir à riqueza presente além do mínimo existencial dos indivíduos, sob pena de afronta à dignidade humana desses. Tributando-se o mínimo existencial, estaria prejudicada a parcela de "riqueza" correspondente, unicamente, ao custeio de despesas básicas necessárias - ou muitas vezes aquém - à garantia do exercício do referido direito fundamental. Logo, forçoso reconhecer que, “(...) a obrigação tributária não pode surgir onde falte totalmente capacidade contributiva e, somente onde esteja presente, torna-se metro de medida do saque tributário"65.

Cabe esclarecer que o presente trabalho apoia-se na ideia de que a tributação diante dessa circunstância - aquém do mínimo existencial - mostra-se impossível ante a inexistência de capacidade contributiva nas situações em que apenas se manifesta a "riqueza" suficiente à preservação do mínimo vital e, não obstante existirem posicionamentos divergentes no que se refere à fundamentação da impossibilidade de incidência desse tipo de tributação - há os que consideram hipótese de inexistência de capacidade contributiva, outros de imunidade e ainda os que consideram hipótese de isenção - fato pacífico é a impossibilidade de exercício do poder de tributar nessa hipótese.

Diante disso, resta clara a íntima relação existente entre capacidade contributiva e a preservação do mínimo existencial dos indivíduos, pois, frise-se, adotando-se o posicionamento segundo o qual não há demonstração de capacidade contributiva na "riqueza" destinada à manutenção do mínimo existencial, não há que se cogitar de tributação onde não houver manifestação de capacidade contributiva, uma vez que, do contrário, o "mínimo indispensável”"66 seria alcançado.

64 COSTA, Regina Helena. Princípio da capacidade contributiva. 4. ed. São Paulo: Malheiros, 2012, p. 71.

65 VALADÃO, Alexsander Roberto Alves. O mínimo existencial e as espécies tributárias. Curitiba, 2008. 347 f. Tese (Doutorado em Direito) - Universidade Federal do Paraná, 2008. Disponível em: <http://dspace.c3sl.ufpr.br:8080/dspace/bitstream/handle/1884/18288/Alexsander\%20Roberto\%20Alves\%20Valadao\%20\%28tese\%29.pdf? sequence=1>. Acesso em: 6 set. 2014, p. 47.

66 Alfredo Augusto Becker apud COSTA, Regina Helena. Op. cit., p. 72. 
Nesse sentido, como preleciona Alfredo Augusto Becker apud Regina Helena Costa:

(...) o dever jurídico que a regra constitucional impõe ao legislador ordinário não é apenas o de escolher fatos-signos presuntivos de renda ou capital para a composição da hipótese de incidência do tributo, mas também e principalmente o dever de criar isençôes tributárias que resguardem a imunidade tributária do mínimo indispensável de capital e renda (...) (grifos originais) ${ }^{67}$

Proteger a "riqueza" correspondente à manutenção do mínimo vital do indivíduo, de modo a fazer com que o Estado se abstenha de tributar essas situações, não se constitui meramente em limitação ao poder de tributar. Mais que isso, representa "o marco determinante da própria competência tributária do Estado" ${ }^{68}$, uma vez que, em contraponto ao poder de tributar do Estado, há o dever imposto a esse de respeitar e permitir "a toda pessoa uma porção material básica de bens que sejam voltados para a satisfação de suas necessidades elementares" ${ }^{\prime 69}$. Essa porção, embora se refira a um conceito - de mínimo existencial - que deva ser aceito universalmente, é passível de adaptações e mutações conforme a região ou país onde o indivíduo se localize $e^{70}$ e, ainda, de acordo com tempo, sendo, portanto, um conceito que "varia no tempo e no espaço" ${ }^{\text {. }}$.

Ademais, cabe ressaltar que, embora o fundamento precípuo da impossibilidade de se tributar o mínimo existencial das pessoas se encontre na preservação da dignidade humana de cada um, merece também enfoque o fato de que, admitindo-se tal hipótese, ao Estado caberia proporcionar condições de sobrevivência aos indivíduos cuja riqueza mínima foi retirada por meio da tributação, fato inadmissível, tendo em vista que "(...)Num Estado Liberal não é permitido que o mínimo existencial seja subtraído pela tributação, parcial ou totalmente, e uma compensação seja dada em benefícios previdenciários. O Estado não pode, como Estado Tributário, subtrair o que, como Estado Social, deve devolver"72.

Ainda, válido destacar que uma tributação nesses moldes acabaria por gerar ainda mais prejuízo ao erário público, uma vez que, além de gerar custos decorrentes

67 Ibidem, p. 72.

68 VALADÃO, Alexsander Roberto Alves. Op. cit., p. 44.

69 Ibidem, p. 30.

70 Ibidem p. 31.

71 COSTA, Regina Helena. Op. cit., p. 74.

72 TIPKE, Klaus; YAMASHITA, Douglas. Op. cit., p. 34. 
-• Tributação, direitos fundamentais e desenvolvimento

do financiamento de despesas essenciais à sobrevivência dos indivíduos que não mais tiverem condições de custeá-la em razão da incidência da tributação, faria com que o Estado movesse a máquina pública arrecadatória. Essa, por sua vez, mostra-se excessivamente onerosa, sobretudo na cobrança de valores irrisórios e, assim, consequentemente, os custos necessários não seriam compensados pelos valores arrecadados. Nessa linha, complementa José Souto Maior Borges apud Regina Helena Costa ${ }^{73}$ :

(...) é ditada [a impossibilidade de se tributar o mínimo existencial] por considerações sociais de diversa natureza, tais como: I - conveniência prática, dada a improdutividade do imposto em confronto com as despesas de arrecadação; II - justiça fiscal; os pequenos contribuintes em estágio de vida social inferior não deverão ter ainda mais reduzida a sua capacidade financeira; III - compensação econômico-financeira, porque os pequenos contribuintes são os que suportam mais duramente os ônus dos impostos indiretos.

No entanto, em que pese o entendimento pacificado segundo o qual a tributação incidente sobre o mínimo existencial configura-se como clara violação ao princípio da capacidade contributiva e, consequentemente, mostra-se inconstitucional, válido tecer comentários acerca dos elementos identificadores do conceito de mínimo existencial, pois conforme já mencionado, tal conceito é suscetível de variação no espaço e no tempo e, assim, muitas vezes, poderá ser considerado de difícil identificação. Portanto, mostra-se necessária a análise de seus dois elementos identificadores: o objetivo e o subjetivo.

Pela análise do elemento objetivo, tem-se que é necessário examinar as características do bem a ser tributado - renda dinâmica ou estática - de modo a perquirir o quão essencial é para a satisfação das necessidades vitais dos indivíduos. Assim, identificam-se quais bens serão beneficiários da não incidência do tributo em virtude de pertencerem à porção patrimonial necessária à sobrevivência, o que, por sua vez, fará com que, v.g., não seja admitido que um bem considerado supérfluo seja enquadrado como essencial às necessidades vitais da pessoa. Com isso, para fins de identificação do mínimo existencial dos indivíduos, caracterizada está a necessidade de se aferir a essencialidade do bem, análise que pode ser feita considerando a sua natureza ou a sua destinaçãa ${ }^{74}$.

73 COSTA, Regina Helena. Op. cit., p. 73.

74 VALADÃO, Alexsander Roberto Alves. Op. cit., p. 77. 
Quando a tributação incide sobre a renda dinâmica do indivíduo de forma direta, caso, por exemplo, do imposto de renda, está tributando diretamente o dinheiro auferido pela pessoa. O dinheiro não demonstra, por si só, a sua essencialidade frente à manutenção do mínimo vital dos indivíduos, sendo fundamental, portanto, analisar a destinação que o indivíduo dará para o dinheiro auferido. Dessa forma, será possível "identificar na renda a proteção existencial, já que [o elemento funcional] impõe que, no plano jurídico, o bem protegido seja afetado pelo seu titular para a satisfação elementar da pessoa ou de sua família”75.

Por outro lado, na hipótese de o fato gerador do tributo referir-se a bem adquirido pela renda dinâmica do indivíduo, o elemento funcional não será o responsável por caracterizar a proteção inerente ao mínimo existencial, pois a própria natureza do bem a ser tributado será capaz de indicar a "aptidão para a satisfação de uma necessidade elementar" ${ }^{\text {76, }}$ que, por sua vez, consubstancia-se, sobretudo, no exercício dos direitos fundamentais constitucionalmente garantidos. Assim, podem-se considerar como objeto da referida proteção, v.g., os alimentos de primeira necessidade, peças de vestuário necessárias à sobrevivência, objetos fundamentais à saúde e, ainda, o local onde o indivíduo exercer sozinho ou junto à sua família, o seu direito à moradia, afinal, tal direito é fundamental à preservação da dignidade da pessoa humana.

Logo, ressalta-se que não será o preço do bem que indicará sua essencialidade. Inegável que tanto a aquisição - compra ou aluguel - quanto a manutenção do local onde se exerce o direito à habitação mostram-se extremamente custosos, no entanto, forçoso reconhecer que o alto despendimento não é feito para a manutenção de despesas supérfluas, mas sim, para a garantia do exercício de um direito constitucionalmente garantido a todos, fato capaz de justificar a proteção do mínimo existencial também referente ao imóvel destinado à moradia.

Entretanto, válido salientar que se torna fundamental uma análise casuística, haja vista que, com o até aqui exposto, não se pretende sugerir ou defender que todos os imóveis potencialmente destinados à habitação merecem a proteção do mínimo existencial. Não há que se considerar, por exemplo, que diversos imóveis destinados à moradia e pertencentes a uma mesma pessoa merecem a referida proteção, uma vez que, dessa forma, superar-se-ia em excesso o mínimo existencial.

Ibidem, p. 78-79.

76 Ibidem, p. 77. 
•• Tributação, direitos fundamentais e desenvolvimento

Seguindo a mesma linha de raciocínio, com relação aos alimentos, não se pretende enquadrar, por exemplo, o caviar como alimento essencial à manutenção das necessidades básicas do sujeito.

No que tange ao elemento subjetivo, busca-se identificar as pessoas aptas a serem beneficiadas pela proteção ao mínimo existencial, ou seja, quem poderá ser o seu titular. Em um primeiro momento, imagina-se que apenas aos hipossuficientes caberia tal benefício, no entanto, após uma análise mais aprofundada, forçoso reconhecer que "também os ricos destinam parte de sua riqueza para a manutenção de suas necessidades básicas", assim, por mais que soe um tanto paradoxal, não há porque privar os mais abastados de tal benefício. Nesse sentido, válido destacar lição de Ricardo Lobo Torres apud Alexsander Roberto Alves Valadão ${ }^{77}$ :

O status negativus do mínimo existencial se afirma, no campo tributário, através das imunidades fiscais: o poder de imposição do Estado não pode invadir a esfera da liberdade mínima do cidadão representada pelo direito à subsistência. Mas essa imunidade é paradoxal, eis que protege tanto o pobre quanto o rico, dentro dos limites mínimos necessários à garantia da dignidade humana.

Como já foi exposto, o fundamento precípuo da impossibilidade de se tributar o mínimo existencial encontra-se na inexistência de capacidade contributiva nessa parcela de renda e, em virtude disso, "não há que se fazer distinção entre os que possuem apenas patrimônio suficiente para sua sobrevivência, e os que têm recursos sobejantes $(. . .)^{78 "}$, pois ambas as classes da sociedade consomem produtos de primeira necessidade, que, por sua vez, inequivocamente, merecem proteção.

Sendo assim, forçoso considerar que, tratando-se de bens de primeira necessidade, a proteção ao mínimo existencial deve restar garantida independentemente da quantidade de riqueza em excesso do sujeito, haja vista que a premissa predominante deve ser aquela apta a garantir a proteção do mínimo existencial a todos os bens que, pelas características de sua natureza ou por sua destinação, estejam "relacionados às condiçôes de existência do seu titular" 79 , independentemente de ser esse rico ou pobre.

Por fim, imprescindível reconhecer que a proteção do mínimo existencial deve ocorrer em relação a todo e qualquer tributo, sob pena de restar inócuo o seu objetivo. Se, por exemplo, de um lado não se onerar a renda correspondente ao

\footnotetext{
Ibidem, p. 169.

78 Ibidem, p. 169.

79 Ibidem, p. 170.
} 
mínimo existencial do indivíduo e, noutro giro, admitir-se o gravame tributário sobre bens referentes a esse mínimo protegido, os efeitos da não tributação sobre a renda estariam anulados, uma vez que não haveria a efetiva proteção do mínimo vital do indivíduo em razão da tributação onerosa incidente diretamente sobre os bens, demonstrando-se, mais uma vez, a íntima relação existente entre a renda dinâmica e a estática dos indivíduos. Com isso, merece destaque o seguinte excerto:

(...) não há efetivamente razão para se proteger, mediante categoria jurídica tão importante, e de tão nobres finalidades, apenas a renda das pessoas, já que, sendo assim, ela se tornaria pífia, e um mero arremedo de proteção, se, na outra ponta, quando essa renda fosse transformada em bens vitais - como alimentos, v.g.-, fossem pagos integralmente os impostos correspondentes ao consumo. Não há dúvida que haveria apenas uma proteção retórica, pois essa renda, que não revela capacidade contributiva, estaria sendo tributada da mesma maneira, ainda que modo oblíquo, através dos bens vitais com ela adquiridos ${ }^{80}$.

\subsection{Tributação sobre o patrimônio e o princípio do não confisco}

Se, por um lado, como visto no tópico anterior, a tributação é limitada pelo mínimo existencial dos indivíduos - não podendo, portanto, estar aquém desse de igual forma, não se pode admitir que a tributação incida tão excessivamente ao ponto de "subtrair mais do que uma parte razoável do patrimônio ou da renda do contribuinte" 81 , ou seja, não se mostra admissível a ocorrência de tributação com efeito confiscatório.

Confisco, segundo lição de Regina Helena Costa, “é absorção total ou substancial da propriedade privada, pelo Poder Público, sem a correspondente indenização”. A partir de tal conceituação, pode-se depreender que não se trata de uma medida a ser comumente utilizada pelo Poder Público, mas, ao contrário, deve ser excepcional, uma vez que impede ou prejudica significativamente o exercício do direito à propriedade privada - e, consequentemente, de outros direitos fundamentais, tais como o direito à moradia -, bem como da livre iniciativa. Nesse sentido, válido destacar entendimento de Douglas Yamashita e Klaus Tipke ${ }^{82}$, ao justificar a vedação imposta constitucionalmente à utilização do tributo com efeito de confisco:

\footnotetext{
80 Ibidem, p. 181.

$81 \quad$ SILVA, José Afonso da. Op. cit., p. 669.

82 TIPKE, Klaus; YAMASHITA, Douglas. Op. cit., p. 68.
} 
-. Tributação, direitos fundamentais e desenvolvimento

(...) a proibição de tributo com efeito de confisco é um valor positivado como princípio constitucional, resultante de três direitos fundamentais, a saber: o direito de propriedade (arts. 50, caput, e inciso XXII, e 170, II, da CF/1988 = direito de uso, gozo e disposição da propriedade), o direito à herança (art. 5, caput, e inciso XXX, da $\mathrm{CF} / 1988$ = direito de auferir propriedade) e o direito ao livre exercício de qualquer trabalho, ofício ou profissão (arts. 10, IV, e 5º, XIII, da CF/1988 = direito de auferir propriedade". (grifos originais)

Outrossim, necessário considerar que o confisco, além de ser excepcional, é uma conduta que, quando adotada, está intimamente correlacionada com a ideia de punição ou sanção - que, consequentemente, pressupõe a prática de ato ilícito - afinal, "É cediço que a riqueza que é tributada a ponto de exaurir-se - cunho confiscatório -, e em relação à qual não é observado o princípio da capacidade contributiva, tende ou a eliminar a fonte de riqueza do sistema ou a depauperá-la até que seja totalmente inviabilizada" ${ }^{\prime 3}$.

Noutro giro, recorrendo-se novamente ao conceito de tributo disposto no art. $3^{\circ}$ do CTN, tem-se que tributo é prestação pecuniária que não pode se constituir como sanção de ato ilícito, ou seja, o detentor do poder de tributar não pode utilizar esse instrumento precipuamente arrecadatório como forma de punição por algum ato ilícito praticado pelo contribuinte, logo, não há que se cogitar a possibilidade de tal instrumento ser utilizado para fins confiscatórios, que, conforme mencionado, caracteriza-se como forma de punição contra a prática de ato ilícito.

Em consonância com tal entendimento, a CRFB/1988 estabelece expressamente em seu art. 150, inciso IV, que a conduta dos entes políticos que implique utilização de tributo com efeito de confisco é vedada. Note-se que, embora pudesse ser possível ou lógico presumir a vigência dessa vedação no ordenamento jurídico pátrio, em virtude da consagrada proteção ao direito à propriedade privada, a CRFB/1988 optou por deixar expressa a vedação ao confisco, fato que pode ser atribuído à pretensão do constituinte de conferir aos cidadãos efetiva proteção à propriedade de cada um, tal qual preleciona Dino Jarach apud Hugo de Brito Machado $^{84}$ :

(...) se a constituição garante amplamente o direito de propriedade, que considera inviolável, só admite a desapropriação nos casos estabelecidos em lei e mediante prévia indenização, e veda a pena de confisco, mas não veda os impostos confiscatórios,

\footnotetext{
VALADÃO, Alexsander Roberto Alves. Op. cit., p. 53.

84 MACHADO, Hugo de Brito. Tributo com efeito de confisco. Revista Dialética de Direito Tributário, Rio de Janeiro, n. 166, p. 93-113, jul. 2009, p. 97.
} 
A aplicação do princípio da capacidade contributiva na tributação...

limitando-se determinar que o Congresso estabelecerá os impostos, a consequência lógica que qualquer intérprete constitucional extrairia desse texto 'es la seguinte: que los Constituyntes han querido, en materia impositiva, salvaguardar el derecho de propriedad con una garantia meramente formal. El derecho de propriedade está a salvo, quando los impuestos sean aprobados por ley del Congreso. Eso es lo que el texto de la Constituición expresa'.

No entanto, em que pese a consagração do princípio do não confisco no texto constitucional vigente, a alta carga de indeterminação do conceito faz com que esteja longe de pacificação a questão sobre a fixação da fronteira existente entre a tributação protegida pelo texto constitucional e a eivada de inconstitucionalidade, em razão de seu caráter confiscatório.

A pretensão de fixar uma limitação imutável de valores máximos de tributos para não configuração do confisco mostra-se inalcançável, sendo necessária uma análise casuística, haja vista que a tributação não incide de maneira igual sobre todas as pessoas e, então, a partir disso, forçoso reconhecer

(...) que um imposto sobre o patrimônio pode ser, sob tal aspecto, confiscatório para uns e para outros não. $\mathrm{O}$ contribuinte que auferir renda elevada poderá pagar o imposto sem sacrificar parcela de seu patrimônio, enquanto outro com renda baixa ou sem nenhuma renda, terá de sofrer redução patrimonial (... $)^{85}$.

Noutro plano, deve-se indagar o correto alcance da vedação ao confisco disposta no art. 150, inciso IV da CRFB/1988. Essencial considerar que embora um único tributo, com valor irrisório, incidente sobre o patrimônio, não configure sacrifício patrimonial do indivíduo, ao se analisar que sobre o mesmo patrimônio incidem diversos tributos que, considerados em conjunto, representam carga tributária excessivamente alta, estaria gerada uma situação em que a tributação seria capaz de causar diminuição significativa, ou mesmo, extinção do patrimônio do contribuinte - embora, considerados individualmente, não manifestem grande expressão econômica. Assim, faz-se necessário indagar se a análise acerca da ocorrência ou não de confisco do patrimônio por meio de tributo deve considerar a incidência desse de forma individual ou em relação à totalidade de carga tributária incidente sobre um mesmo patrimônio.

Conforme Hugo de Brito Machado assevera, é pacífico o entendimento segundo o qual a melhor interpretação a ser adotada sobre um dispositivo é aquela

85 Ibidem, p. 95. 
•• Tributação, direitos fundamentais e desenvolvimento

que permita a máxima eficácia possível do preceito que se busca alcançar ${ }^{86}$. Com isso, reconhecer que o confisco, pela via da tributação, deveria ser analisado individualmente em cada tributo incidente sobre o patrimônio, significaria restringir a proteção pretendida pelo constituinte ao prescrever a regra constante na Carta Política, em seu art. 150, inciso IV.

Note-se que o texto constitucional dispõe ser expressamente vedado "utilizar tributo com efeito de confisco" "87, não restringindo a vedação à mera instituição de tributo com efeitos confiscatórios, pois, se assim fosse, ao Poder Público seria autorizado instituir uma infinidade de tributos desde que, considerados isoladamente, não implicassem confisco do patrimônio, circunstância que, por óbvio, não impediria que o fisco confiscasse parcela ou totalidade do patrimônio individual. Nesse sentido, válido o seguinte posicionamento:

Note-se que a Constituição não se refere a instituição de um tributo com efeito de confisco, mas da utilização do tributo com efeito de confisco. Isto quer dizer que não é um tributo, especificamente considerado, que pode ter o efeito de confisco, e sim que qualquer tributo pode, eventualmente, em face das circunstâncias do caso concreto, ter o efeito de confisco. (...) Aliás, se o efeito de confisco fosse examinado em face de cada tributo especificamente, o Poder Público bem poderia praticar o confisco mediante a instituição e cobrança de vários tributos sem que nenhum deles, isoladamente, pudesse ser tido como confiscatório ${ }^{88}$.

Em consonância com o referido entendimento, encontra-se posição adotada pelo Supremo Tribunal Federal, conforme pode ser percebido no excerto do seguinte julgado transcrito a seguir:

(...) Resulta configurado o caráter confiscatório de determinado tributo, sempre que o efeito cumulativo - resultante das múltiplas incidências tributárias estabelecidas pela mesma entidade estatal - afetar, substancialmente, de maneira irrazoável, o patrimônio e/ou os rendimentos do contribuinte. - O Poder Público, especialmente em sede de tributação (...) não pode agir imoderadamente, pois a atividade estatal acha-se essencialmente condicionada pelo princípio da razoabilidade $(. . .)^{89}$.

Ibidem, p. 98-99.

87 BRASIL. Constituição (1988). Constituição da República Federativa do Brasil. Brasília, Distrito Federal: Senado, 1988.

88 Hugo de Brito Machado apud Hugo de Brito Machado. Op. cit., p. 99.

89 BRASIL, Supremo Tribunal Federal. Recurso Extraordinário n. 632.795/MG. Relator Ministro Dias Toffoli. Brasília, DF, 07 de novembro de 2011. DJe 14.11.2011. Disponível em: $<$ http://stf.jusbrasil.com.br/jurisprudencia/22876134/recurso-extraordinario-re-632795-mg-stf>. Acesso em: 22 set. 2015. 
Assim, por todo o exposto até aqui, essencial reconhecer que o que definitivamente determina a ocorrência ou não do confisco é a correta aplicação do princípio da razoabilidade, tendo em vista que os efeitos confiscatórios dos tributos advêm, justamente, da sua incidência de forma irrazoada sobre o patrimônio dos contribuintes, culminando com a extinção integral deste ou, ao menos, com sua perda significativa.

Contudo, exatamente em razão da forte influência do referido princípio na configuração do confisco e sua consequente relatividade, mostra-se necessária a análise casuística das situações geradas pela tributação sobre o patrimônio dos contribuintes. Ressalte-se que o que se configura como razoável para um determinado indivíduo, pode não ser em relação a outro por conta das particularidades de cada caso. Nesse sentido, conclui Luciano Amaro $^{90}$ :

O princípio da vedação de tributo confiscatório não é um preceito matemático; é um critério informador da atividade do legislador e é, além disso, preceito dirigido ao intérprete e ao julgador, que, à vista das características da situação concreta, verificarão se determinado tributo invade ou não o território do confisco. (grifo original).

\section{O APERFEIÇOAMENTO DA APLICAÇÃO DA CAPACIDADE CONTRIBUTIVA NA TRIBUTAÇÃO SOBRE O PATRIMÔNIO DESTINADO À MORADIA - IPTU E ITR}

\subsection{Noções introdutórias sobre o IPTU e o ITR}

O Imposto Predial e Territorial Urbano (IPTU) e o Imposto Territorial Rural (ITR) compõem a categoria dos impostos reais, o que significa afirmar que seus respectivos objetos de incidência integram o patrimônio do contribuinte. No entanto, é importante ressaltar que eles se diferenciam dos demais impostos dessa espécie, uma vez que a circunstância essencial para as suas cobranças não é a mera aquisição da propriedade, posse com animus domini ou domínio útil de um, mas sim a manutenção dessas qualidades no momento eleito para ocorrer a incidência tributária.

Dessa forma, pode-se compreender que o IPTU e o ITR têm como traço em comum uma hipótese de incidência capaz de refletir as relaçóes contínuas do contribuinte com o bem imóvel, motivo pelo qual é válido destacar que os referidos impostos não se esgotam em um único pagamento, mas, ao contrário, perpetuam-se

90 AMARO, Luciano. Op. cit., p. 168. 
•• Tributação, direitos fundamentais e desenvolvimento

enquanto perdurarem as mencionadas relações capazes de atrair a incidência do IPTU e do ITR - propriedade, posse ou domínio útil de bem imóvel.

Diante disso, forçoso reconhecer que a periodicidade no pagamento de tais impostos é um fator capaz de influir diretamente no exercício do direito fundamental à moradia, que, conforme já observado no capítulo anterior, foi alçado à categoria dos direitos inerentes à pessoa humana, com especial proteção constitucional.

Nesse sentido, destaca-se que mesmo o imóvel considerado como bem de família não estará protegido frente às dívidas relacionadas a tais impostos, tendo em vista que, nos termos do art. 3º, inciso IV, da Lei 8.009/90, os débitos de impostos, taxas e contribuições devidos em função do imóvel familiar, tais como IPTU e ITR, excepcionam a regra da impenhorabilidade do bem de família. Assim, mostra-se essencial manter o pagamento periódico dos mencionados impostos, sob pena de tal constrição atingir essa espécie de bem e, por conseguinte, afetar também o direito à moradia dos contribuintes inadimplentes.

Por oportuno, válido registrar que inobstante IPTU e ITR apresentarem similitudes, os pontos distintivos também devem ser objeto de destaque, conforme a seguir se fará.

A começar pelos comentários atinentes ao IPTU, imposto de competência municipal com previsão no art. 156, inciso I, da Constituição da República Federativa do Brasil, tem-se que sua hipótese de incidência é a propriedade, posse ou domínio útil de um bem imóvel por natureza ou por acessão física e localizado, em regra, na área urbana do município.

Note-se que, diferentemente do que ocorre em outras áreas, para fins tributários, a zona urbana de cada município não estará caracterizada meramente pela delimitação feita pelas leis de zoneamento. Assim, mostra-se essencial também a existência de pelo menos dois dos melhoramentos constantes nos incisos do $\$ 1^{\mathrm{o}}$, do art. 32, do $\mathrm{CTN}^{91}$, para que, então, considere-se a área como pertencente à zona

Art. 32. O imposto, de competência dos Municípios, sobre a propriedade predial e territorial urbana tem como fato gerador a propriedade, o domínio útil ou a posse de bem imóvel por natureza ou por acessão física, como definido na lei civil, localizado na zona urbana do Município. $\$ 1^{\circ}$ Para os efeitos deste imposto, entende-se como zona urbana a definida em lei municipal; observado o requisito mínimo da existência de melhoramentos indicados em pelo menos 2 (dois) dos incisos seguintes, construídos ou mantidos pelo Poder Público: I-meio-fio ou calçamento, com canalização de águas pluviais; II - abastecimento de água; III - sistema de 
urbana da cidade. Entretanto, cabe ressaltar que, conforme assente jurisprudência do Superior Tribunal de Justiça $(\mathrm{STJ})^{92}$, é possível a cobrança do IPTU em áreas que, embora não sejam beneficiadas pelos melhoramentos expostos pelo dispositivo anteriormente mencionado, tenham sido transformadas, pela lei de zoneamento urbano, em áreas urbanizáveis ou de expansão urbana, tal como preleciona o $\$ 2^{\circ}$ do art. 32 do CTN.

Outrossim, tratando-se o IPTU de um imposto cobrado em razão de certas relações sobre um bem imóvel por natureza ou por acessão física, sua base de cálculo será o valor venal do imóvel que, sendo caracterizado como "aquele preço que seria alcançado em uma operação de compra e venda à vista, em condições normais do mercado imobiliário, admitindo-se a diferença de até 10\% para mais ou para menos" $" 93$, abrangerá tanto o valor do terreno - bem imóvel por natureza - quanto o valor das edificações - bem imóvel por acessão física - mediante análise de diversos elementos, tais como os descritos por Leandro Paulsen ${ }^{94}$ :

(...) preços correntes das transações e das ofertas à venda no mercado imobiliário, custos de reprodução, locações correntes; características da região em que se situa o imóvel; face de quadras a quadras ou quarteirōes; características da região em que se situa o imóvel; a logradouros; profundidade, terrenos encravados; de fundo interno; idade do imóvel; reconstrução, ampliação etc. (...).

Já no que tange ao ITR, trata-se de imposto de competência da União, com previsão no art. 153, inciso VI da CRFB/1988, cujo produto da arrecadação, no entanto, poderá ser revertido integralmente ao município que optar por fiscalizar e cobrar tal imposto, nos termos do art. 158 , inciso II c/c art. $153, \$ 4^{\circ}$, III, ambos da CRFB/88.

esgotos sanitários; IV - rede de iluminação pública, com ou sem posteamento para distribuição domiciliar; $V$-escola primária ou posto de saúde a uma distância máxima de 3 (três) quilômetros do imóvel considerado (...). (Grifou-se)

92 A título exemplificativo, válida a consulta dos seguintes julgados a respeito do tema em comento: AREsp 696.431/SP 2015/0080753-1; AgRg no REsp 783.794/SP 2005/0159477-5 e REsp 783.794.

93 HARADA, Kiyoshi. Valor venal. Prevalência do conceito legal. Disponível em: <http://www. ambito-juridico.com.br/site/index.php?n_link=revista_artigos_leitura\&artigo_id=2839>. Acesso em: 19 jul. 2015.

94 PAULSEN, Leandro. Impostos federais, estaduais e municipais. In: PAULSEN, Leandro; MELO, José Eduardo Soares de. 7. ed. rev. e atual. Porto Alegre: Livraria do Advogado Editora, 2012, ISBN 978-85-7348-786-2, item 1.4 - capítulo 1 (parte III), e-book. 
-. Tributação, direitos fundamentais e desenvolvimento

Tal como assevera o art. 29 do CTN, a hipótese capaz de atrair a incidência de tal imposto é a propriedade, o domínio útil ou a posse com animus domini de bem imóvel por natureza localizado, como regra, na zona rural do município, de acordo com o previsto na respectiva lei de zoneamento e observadas as considerações anteriormente feitas sobre o $\$ 1^{\circ}$ do art. 32 do CTN.

Note-se, entretanto, que o referido critério territorial não se mostra absoluto para fins de determinar a incidência do ITR, sendo possível a sua relativização através da adoção de outro critério. Dessa forma, mostra-se plenamente aplicável o critério da destinação econômica do imóvel e, sendo assim, se esse bem, comprovadamente, for explorado com atividade agrária, o imposto que poderá ser cobrado é o ITR, ainda que tal imóvel localize-se em área qualificada como de zona urbana. Tal entendimento encontra amparo no disposto no art. 15 do Decreto-Lei 57/1966, diploma legal recebido no ordenamento jurídico pátrio como lei materialmente complementar e plenamente aplicável e apto a delimitar a incidência tributária sobre imóveis, in verbis:

Art. 15 DL 57/66. O disposto no art. 32 da Lei n. 5.172, de 25 de outubro de 1966, não abrange o imóvel de que, comprovadamente, seja utilizado em exploração extrativa vegetal, agrícola, pecuária ou agroindustrial, incidindo assim, sobre o mesmo, o ITR e demais tributos com o mesmo cobrados.

Válido registrar que a utilização de ambos os critérios - territorial e destinação econômica - mostra-se essencial, uma vez que é um fator determinante para evitar a ocorrência do fenômeno da bitributação. Tratando-se o ITR e o IPTU de impostos incidentes sobre a propriedade, o domínio útil ou posse com animus domini de bem imóvel, as características desse bem serão as responsáveis por determinar o âmbito de abrangência de um e outro imposto.

Oportuno, ainda, ressaltar que outro fator distintivo entre ITR e IPTU é no que tange à base de cálculo, tendo em vista que, diferentemente do que ocorre com o imposto municipal imobiliário, a dimensão numérica do fato gerador do ITR desconsidera quaisquer acessões físicas edificadas sobre o imóvel por natureza. Assim, sua base de cálculo será o valor da terra nua tributável, o que, por conseguinte, diminuirá consideravelmente o valor da arrecadação dessa exação tributária.

Feitas essas considerações, forçoso reconhecer também a necessidade de se perquirir a intensidade adequada à cobrança de ambos os impostos aqui analisados para que, então, seja possível garantir aos contribuintes uma cobrança segundo os ditames da capacidade contributiva e, consequentemente, justa. 
Frise-se que tais impostos possuem estreita relação com o exercício ao direito à moradia, conforme já explicado e, com isso, a preocupação com a fixação das alíquotas merece especial atenção. Isso porque tal elemento determinará a intensidade da tributação e, consequentemente, será responsável por posicionar o valor da cobrança entre o mínimo existencial e o confisco, ou seja, dentro dos limites mínimo e máximo da capacidade contributiva para que, então, seja possível a realização da justiça fiscal.

\section{2. Capacidade contributiva e a progressividade de alíquotas no IPTU e no ITR}

\subsubsection{Breves considerações sobre o quantum debeatur dos tributos}

A base de cálculo e as alíquotas tributárias são os elementos responsáveis por determinar o quantum debeatur (valor a ser pago) dos tributos, integrando, portanto, o critério prestacional ou quantitativo das respectivas regras matrizes de incidência. Ou seja, com a identificação de tais elementos, torna-se possível auferir "a dimensão da obrigação pecuniária, positivando o quantum devido" 95 .

Considera-se a base de cálculo como o elemento capaz de identificar a expressão numérica do núcleo do tipo dos tributos, motivo pelo qual se mostra essencial existir uma correlação entre o fato gerador e a base de cálculo dos tributos. Assim, no caso do IPTU e do ITR, as respectivas bases de cálculo deverão ser capazes de quantificar, numericamente, o imóvel urbano ou rural objeto da tributação, daí o acerto na escolha do valor venal do imóvel e do valor da terra nua tributável como critérios aptos a "quantificar o objeto da imposição fiscal"

Cabe ressaltar, no entanto, que a identificação da base de cálculo dos impostos e dos demais tributos não é suficiente para dimensionar o quantum de riqueza que deverá ser pago pelo contribuinte ao fisco competente. Há a necessidade de se utilizar as alíquotas, que, em se tratando de um elemento capaz de fornecer o porcentual da riqueza manifestada a ser retirada do contribuinte, irá indicar, por conseguinte, a intensidade que poderá ser retirada do sujeito passivo integrante da relação jurídica obrigacional tributária.

\footnotetext{
95 MELO, José Eduardo Soares de. Dicionário de direito tributário: material e processual. São Paulo: Saraiva, 2012, ISBN 978-85-02-17295-1, e-book.

96 Ibidem.
} 
•• Tributação, direitos fundamentais e desenvolvimento

Note-se, portanto, que as alíquotas são a principal forma de promover a oscilação da carga tributária, bastando, para isso, que elas próprias sejam alteradas. Dessa forma, é essencial perceber a necessidade de se promover um controle rígido sobre as possíveis formas de fixá-las para que, então, seja possível impedir a ocorrência de uma tributação desarrazoada e que, consequentemente, caracterize uma situação de desrespeito à capacidade contributiva efetiva dos sujeitos passivos.

Dessa feita, válido ressaltar a correlação existente entre a necessidade de controle das alíquotas e a aplicação do princípio do não confisco, já elucidado no capítulo anterior, uma vez ser notório perceber que alíquotas imoderadas acarretam uma tributação desarrazoada e, diante disso, consequentemente, a cobrança será eivada de inconstitucionalidade, tendo em vista tal circunstância mostrar-se como um claro desrespeito ao comando constitucional que veda a cobrança de tributos com efeitos confiscatórios (vide art. 150, inciso IV, CRFB/1988).

Inegável reconhecer que na hipótese de se desconsiderar o mencionado princípio, quando da fixação de alíquotas, sua variação fatalmente ultrapassaria a capacidade efetiva de o sujeito passivo contribuir com as despesas do Estado em prol do interesse público e, assim, ao invés de restar caracterizada a hipótese de divisão de riqueza, demonstrar-se-ia, ao contrário, a aniquilação dessa.

Outrossim, oportuno destacar a importância de se recorrer à possibilidade de utilizar alíquotas diferenciadas como outra forma de controle do mencionado elemento. Sabe-se que as alíquotas podem ser uniformes, o que determina a aplicação de uma alíquota única independentemente do valor da base de cálculo ou de outras circunstâncias, ou diferenciadas, permitindo, como o próprio nome sugere, a aplicação de diferentes alíquotas na cobrança de um mesmo imposto.

A princípio, ao permitir que a arrecadação dos tributos ocorra com base em alíquotas diferenciadas, tem-se o entendimento no sentido de que tal cobrança aconteceria como uma forma de prestigiar a aplicação do princípio da capacidade contributiva. No entanto, a utilização desse método, sobretudo quando da análise da progressividade, merece cautela, para que, então, não haja excesso na tributação ou qualquer forma de desproporcionalidade no pagamento de impostos pelos contribuintes.

É possível diferenciar as alíquotas com base em critérios distintos, tais como o grau de essencialidade do bem - tornando as alíquotas seletivas - e a variação da base de cálculo, o que faz com que a alíquota seja elevada na medida em que a base 
de cálculo também aumente, sendo que, diante desta última hipótese, encontra-se inserida uma das facetas do princípio da progressividade.

A característica principal do mencionado princípio reside no fato de que sua aplicação implica elevação da intensidade da tributação, na medida em que se demonstram existentes alguns dos critérios previamente definidos em lei, dependendo, ainda, da finalidade que se pretende alcançar.

Em uma primeira faceta do princípio da progressividade, busca-se elevar a tributação para fins de estimular ou desestimular determinados comportamentos. Nesse sentido, a CRFB/1988 prevê, em seu art. 153, $\$$ 4o, inciso I, que o ITR será progressivo na hipótese de a propriedade rural não ser produtiva, circunstância averiguada com base no disposto no art. $6^{\circ}$ da Lei 8.629/93, ou seja, a produtividade da terra é identificada a partir do seu grau de utilização (GUT) e do grau de eficiência na exploração (GEE). Ainda, é possível observar, no texto constitucional, outra hipótese de progressividade com finalidade extrafiscal, mas em relação ao IPTU, que, conforme disposto no art. 182, $₫ 4^{\circ}$, inciso II, poderá ser progressivo no tempo em caso de violação às normas do plano diretor municipal atinentes à função social da propriedade urbana. Com isso, havendo desrespeito à função social da propriedade e desde que, se possível for, tenha sido aplicada a sanção administrativa prevista no inciso I do mesmo dispositivo constitucional, a progressividade será cabível.

Por outro lado, inegável reconhecer a importância de uma segunda faceta do princípio da progressividade, que, distanciando-se da finalidade de estimular e inibir comportamentos, objetiva, precipuamente, cumprir com a finalidade arrecadatória dos tributos. Para isso, fundamenta-se na elevação da carga tributária de acordo com o aumento da capacidade contributiva dos contribuintes, fator que, por sua vez, torna incerta a possibilidade de aplicação da progressividade fiscal nos impostos reais, tais como o IPTU.

Explica-se: embora seja necessário reconhecer a importância de aplicar-se o princípio da capacidade contributiva aos impostos reais, uma vez que, frise-se, a renda dinâmica do contribuinte sempre será afetada ainda que mediatamente, a jurisprudência tradicional do STF estava fixada no sentido de que a CRFB/1988 apenas teria tornado obrigatória a observância da capacidade econômica dos contribuintes nos impostos pessoais, o que, por sua vez, acabaria por impedir a aplicação de tal princípio aos impostos reais. Assim, considerando que a segunda faceta da progressividade seria caracterizada como um desdobramento do princí- 
•• Tributação, direitos fundamentais e desenvolvimento

pio da capacidade contributiva, não seria cabível também a tributação de impostos reais progressivos, salvo expressa previsão constitucional, tal como ocorre em relação ao IPTU progressivo em razão do valor venal do imóvel, que será analisado adiante.

No entanto, inobstante tal entendimento jurisprudencial ter perdurado por longos anos, sua relativização já se mostra evidente, sobretudo após a surpreendente decisão do Pretório Excelso no sentido de admitir a constitucionalidade do Imposto de Transmissão Causa Mortis e Doação (ITCMD) progressivo ${ }^{97}$, mesmo diante da ausência de disposição expressa sobre a referida progressividade no texto constitucional. Embora não seja escopo do presente trabalho tecer comentários acerca desse imposto, válido salientar que o ITCMD possui natureza real, tal como IPTU e ITR, e, sendo assim, a relativização do posicionamento jurisprudencial tradicional com relação ao imposto ora em comento pode representar o início de uma nova tendência na Suprema Corte, o que, inevitavelmente, contribuirá para a concretização, cada vez mais efetiva, da capacidade contributiva nos impostos reais.

\subsubsection{Progressividade fiscal do IPTU}

Embora muito recentemente o STF tenha relativizado o seu posicionamento de admitir a progressividade em impostos reais apenas nos casos expressamente previstos na Carta Política brasileira, fato é que, com relação ao IPTU, a progressividade fiscal somente restou admitida após a Emenda Constitucional 29, de 2000, responsável por alterar a redação do $\$ 1^{\circ}$ do art. 156, incluindo seus dois incisos, cujo conteúdo indica, respectivamente, a possibilidade de o IPTU ter alíquotas progressivas, em razão do valor venal do imóvel, e diferenciadas, de acordo com a localização e o uso do bem.

BRASIL. Supremo Tribunal Federal. Recurso Extraordinário n. 562.045/RS. Constitucional. Tributário. Lei estadual: progressividade de alíquota de imposto sobre transmissão causa mortis e doação de bens e direitos. Constitucionalidade. Art. $145, \$ 1^{\circ}$, da constituição da república. Princípio da igualdade material tributária. Observância da capacidade contributiva. Recurso extraordinário provido. Recurso Extraordinário n. 562045/RS. Estado do Rio Grande do Sul e Espólio de Emília Lopes de Leon. Relator: Min. Ricardo Lewandowski, Data de Julgamento: 06/02/2013, Tribunal Pleno, Data de Publicação: DJe 27-11-2013, EMENT VOL-02712-01 PP-00001. Disponível em: <http://www.stf.jus.br/portal/jurisprudencia/listarJurisprudencia.asp?s1=\%28RE\%24\%2ESCLA\%2E+E+562045\%2ENUME\%2E\%29+ $\mathrm{OU}+\% 28 \mathrm{RE} \% 2 \mathrm{EACMS} \% 2 \mathrm{E}+\mathrm{ADJ} 2+562045 \% 2 \mathrm{EACMS} \% 2 \mathrm{E} \% 29 \&$ base $=$ baseAcordaos \& url=http://tinyurl.com/acyfaah>. Acesso em: 23 set. 2015. 
Diferentemente do que ocorre no art. 182, $\$ 4^{\circ}$ da CRFB/1988, a progressividade inserida pela EC 29/2000 representa uma hipótese de cobrança do IPTU progressivo com intuito predominantemente arrecadatório, tendo em vista que a variação das alíquotas em sentido crescente ocorre na medida em que haja elevação do valor venal do imóvel a ser tributado.

Antes do advento da referida Emenda Constitucional, embora vigorasse o entendimento que vedava a progressividade fiscal do IPTU, grande parte das leis municipais previam tal forma de tributação sobre os imóveis inseridos em suas respectivas atribuições territoriais, circunstância que acabou por incentivar diversos contribuintes, que se sentiam lesados pela referida cobrança progressiva, a instaurarem processos com o escopo de afastar a aplicabilidade de tais leis, já que eles, utilizando-se de uma interpretação radical, alegavam violação da Constituição, na medida em que esta autorizaria que a capacidade econômica dos contribuintes fosse aferida para promover apenas a gradação dos denominados impostos pessoais.

Assim, diante do Judiciário abarrotado com processos relacionados à controvérsia ora exposta, o julgamento do RE n. 153.771-0/MG tornou-se um leading case e, dessa forma, a decisão de considerar inconstitucional qualquer forma de progressividade fiscal do IPTU funcionou como modelo para resolver os demais processos com questão correlata. Observe-se:

EMENTA: IPTU. Progressividade. No sistema tributário nacional é o IPTU inequivocamente um imposto real. Sob o império da atual Constituição, não é admitida a progressividade fiscal do IPTU, quer com base exclusivamente no seu artigo $145, \S$ $1^{\circ}$, porque esse imposto tem caráter real que é incompatível com a progressividade decorrente da capacidade econômica do contribuinte, quer com arrimo na conjugação desse dispositivo constitucional (genérico) com o artigo 156, $\$ 1^{\circ}$ (específico). A interpretação sistemática da Constituição conduz inequivocamente à conclusão de que o IPTU com finalidade extrafiscal a que alude o inciso II do $\$ 4^{\circ}$ do artigo 182 é a explicitação especificada, inclusive com limitação temporal, do IPTU com finalidade extrafiscal aludido no artigo $156, \mathrm{I}, \mathbb{\$} 1^{\circ}$ Portanto, é inconstitucional qualquer progressividade, em se tratando de IPTU, que não atenda exclusivamente ao disposto no artigo 156, $\$ 1^{\circ}$, aplicado com as limitaçóes expressamente constantes dos $\$ \$ 2^{\circ} \mathrm{e}$ $4^{\circ}$ do artigo 182, ambos da Constituição Federal. Recurso extraordinário conhecido e provido, declarando-se inconstitucional o subitem 2.2.3 do setor II da Tabela III da Lei 5.641, de 22.12.89, no município de Belo Horizonte ${ }^{98}$.

98 BRASIL. Supremo Tribunal Federal. IPTU. Progressividade. Recurso Extraordinário n. 153771/MG. Relator Ministro Carlos Velloso. Brasília, 20 de novembro de 1996. Disponível em: <http://www.stf.jus.br/portal/jurisprudencia/listarJurisprudencia.asp?s1 =IPTU+progre 
•• Tributação, direitos fundamentais e desenvolvimento

No entanto, em que pese o referido julgamento ter pacificado a controvérsia ora exposta, ainda que apenas em âmbito jurisprudencial, a EC 29/2000 tratou de constitucionalizar entendimento diametralmente oposto ao que até então vigorava na Suprema Corte brasileira, uma vez que a referida Emenda Constitucional autorizou os diversos municípios brasileiros a inserirem nas respectivas leis instituidoras de IPTU a possibilidade de cobrar esse imposto com alíquotas diferenciadas - progressivas ou não - na medida em que haja a variação da base de cálculo, bem como considerando diferenças no uso e na localização do imóvel - fatores que, por sua vez, influenciam no valor da base de cálculo do IPTU.

Diante desse novo cenário, a controvérsia que aparentemente mostrava-se superada, ganhou novos contornos, pois, se por um lado, a modificação trazida pela EC 29/2000 tendia a pacificar definitivamente a questão, noutro giro, tal emenda acabou por ter sua constitucionalidade contestada, provocando, por conseguinte, nova manifestação do STF a respeito do tema.

Nessa toada, na tentativa de fundamentar a suposta inconstitucionalidade que estava sendo alegada, diversas vozes argumentavam no sentido de que a inovação promovida pela EC 29/2000 representaria ofensa a direitos e garantias individuais, que, por se tratarem de cláusula pétrea (vide art. $60, \$ 4^{\circ}$, inciso IV da CRFB/88), não poderiam ser suprimidas ou limitadas por força da ação do Poder Constituinte Reformador.

Contudo, forçoso reconhecer que tal argumento não merece prosperar, motivo pelo qual foi prontamente repelido pelo Pretório Excelso, sobretudo nas decisões unânimes proferidas nos julgamentos do RE 423.768/SP e RE 586.693/SP, que, por sua vez, erigiram-se como dois marcos importantes na mudança de posicionamento jurisprudencial, senão vejamos.

Conforme exposto pelo ministro Marco Aurélio, ao proferir seu voto no julgamento de ambos os Recursos Extraordinários supramencionados, o fato de a EC 29/2000 prever a progressividade fiscal do IPTU não representa qualquer violação aos direitos e garantias individuais dos contribuintes, pois há que se atentar que tanto a progressividade quanto à consideração da capacidade econômica dos contribuintes já estavam previstas no ordenamento brasileiro antes mesmo do advento

ssivo\%28153771.NUME.+OU+153771.ACMS.\%29\&base=baseAcordaos>. Acesso em: 14 ago. 2015. 
dessa emenda - vide art. $156, \$ 1^{\circ}$, na redação primitiva, e art. $145, \$ 1^{\mathrm{o}} \mathrm{da}$ $\mathrm{CRFB} / 88$, respectivamente - não havendo, portanto, qualquer inovação.

Destaca-se que tal previsão constitucional não estava adstrita aos impostos denominados pessoais e, sendo assim, como já visto no primeiro capítulo do presente trabalho, não há motivos que justifiquem, adequadamente, a exclusão dos impostos reais quando da análise da capacidade econômica dos contribuintes. Registre-se que, além do fato aqui exposto insistentemente relacionado à profunda correlação entre renda dinâmica e estática, inegável considerar também que, sendo a capacidade contributiva decorrência da igualdade, um dos objetivos fundamentais da República (vide art. 30, inciso III da CRFB/88), deve ser maximamente aplicada a todos os tributos. Nesse sentido, válido destacar o seguinte trecho do voto do ministro Luiz Fux no julgamento do RE 586.693/SP99:

(...) A tese que afasta a progressividade dos impostos reais parte de conceitos abstratos estranhos ao texto constitucional, preconcebidos em teorias que não se ajustam à totalidade normativa da Constituição brasileira de 88, uma vez que a capacidade contributiva, por ser decorrência da cláusula maior da igualdade (CF, art. 5\%, caput, e 150, II), deve, necessariamente, incidir sobre todo e qualquer tributo, como meio de concretização do ideal de justiça fiscal (...).

Como pôde ser observado até aqui, é um equívoco atrelar a mudança trazida pela EC 29/2000 a uma inovação capaz de violar frontalmente uma cláusula pétrea. Ressalta-se que se qualquer inovação proporcionada pela atuação do Poder Constituinte Reformador representasse inconstitucionalidade, estar-se-ia admitindo a fossilização das decisóes políticas tomadas no passado, o que, por sua vez, atentaria contra a democracia brasileira. Seguindo essa linha de pensamento, o eminente ministro Luiz Fux complementa seu voto:

(...) A leitura das cláusulas pétreas, inspirada no princípio democrático, impõe que se reconheça deferências às robustas manifestações democráticas expressadas por meio de Emendas à Constituição, que só podem ser declaradas inconstitucionais quando estiver em jogo o núcleo essencial dos valores protegidos pelo art. $60, \S 4^{\circ}$, da $\mathrm{CF}$, que tutelam, assim, a própria identidade do pacto constitucional de 1988 (...).

Nesse sentido, essencial considerar também o teor da súmula 668 do STF, que acabou por sedimentar o entendimento jurisprudencial ora esposado. $\mathrm{Na}$ medida

99 BRASIL. Supremo Tribunal Federal. IPTU. Progressividade. Recurso Extraordinário n. 586.693/ SP. Relator Ministro Marco Aurélio. Brasília, DF, 09 de dezembro de 2008. Disponível em: <http://www.stf.jus.br/portal/processo/verProcessoAnda mento.asp? incidente $=2617543>$. Acesso em: 20 set. 2015, p. 141-142. 
em que tal súmula expõe que qualquer progressividade fiscal do IPTU instituída por leis municipais anteriores à EC 29/2000 é inconstitucional, ao utilizar uma interpretação a contrario sensu do enunciado, é possível extrair o entendimento de que a progressividade do IPTU instituída após o advento da já referida Emenda Constitucional está em harmonia com a atual Carta da República.

Superada a análise da constitucionalidade da EC 29/2000 e, consequentemente, da possibilidade de os municípios brasileiros cobrarem IPTU de forma progressiva em razão do valor venal do imóvel, é necessário ter cautela no uso dessa forma de tributação, pois, do contrário, tal cobrança poderá se tornar inconstitucional. Conforme já aventado, alíquotas mal calibradas podem levar a uma tributação confiscatória, ultrapassando, por conseguinte, o limite máximo da capacidade contributiva. Sendo assim, tratando-se a progressividade de uma forma de cobrança com variação crescente de alíquotas, o risco de a fixação dessas ser desarrazoada é maior e, diante disso, encontrar um ponto de equilíbrio entre a concretização da igualdade material dos contribuintes e a impossibilidade de confisco adquire extrema importância, sobretudo para consagração da justiça fiscal ${ }^{100}$

(...) Certo que a alíquota progressiva pode resvalar para o desvario do confisco, mas, aí, o caso será de aferição do caráter razoável e proporcional da lei. Controle judicial sobre a atividade legislativo-tributária, então, para que esta nem descambe para a zona da gula arrecadatória nem desequipare contribuintes em situação factual de igualdade (...).

Visto isso, cabe ressaltar, ainda, que embora seja inegável reconhecer que a progressividade é uma das formas pelas quais a capacidade contributiva se manifesta, é um equívoco considerar que entre tais princípios há uma completa identidade, motivo pelo qual é errôneo assentir com a hipótese, por muitos aventada, de que a progressividade é suficiente para consagrar a capacidade contributiva nos impostos reais.

Como insistentemente analisado no presente trabalho, o patrimônio imobilizado do contribuinte, em regra, não é capaz de se auto-sustentar, ou seja, não é apto a pagar as dívidas dele decorrentes, fazendo com que, inevitavelmente, parte da renda móvel tenha que ser comprometida. Logo, embora seja uma tarefa árdua, é

100 BRASIL. Supremo Tribunal Federal. IPTU. Progressividade. Recurso Extraordinário n. 423.768/ SP. Relator Ministro Marco Aurélio. Brasília, DF, 01 de dezembro de 2010. Disponível em: <http://www.stf.jus.br/portal/processo/verProcessoAndamento.asp? incidente=2219868>. Acesso em: 20 set. 2015, p. 322. 
necessário recorrer à utilização de outros critérios que conservem a natureza real do IPTU e do ITR e, simultaneamente, proporcionem uma maior individualização da cobrança, atendendo, portanto, aos reclames da justiça fiscal.

\subsection{Importância de se proceder com cautela na individualização dos contribuintes}

Se por um lado, a progressividade não se mostra suficiente para efetivar, de forma plena, o princípio da capacidade contributiva nos impostos reais, noutro giro, essencial considerar também que a utilização de outros critérios para mensurar a tributação exige extrema cautela, uma vez que, do contrário, a essência dessa espécie de impostos poderia ser desnaturada e a cobrança tenderia a ser preenchida com grande insegurança e incerteza dentre os contribuintes.

O IPTU e o ITR integram a categoria dos impostos reais e, mais especificamente, representam uma forma de tributação em que o fisco realiza a cobrança após a ocorrência de uma hipótese de incidência voltada a uma conduta relacionada ao patrimônio imobilizado do contribuinte. Assim, a fim de preservar a natureza desses impostos, o valor do pagamento a ser efetuado pelo sujeito passivo, na medida do possível, deve se referir ao bem imóvel envolvido na cobrança.

Ademais, é preciso notar que a ausência de correlação entre o bem imóvel e os critérios de mensuração da tributação demonstra também carência na delimitação dos motivos que justificam a relação jurídica obrigacional tributária instaurada entre a Fazenda Pública municipal e os contribuintes do IPTU e do ITR.

Inevitavelmente, tais circunstâncias fazem surgir um ambiente tomado por insegurança jurídica, tendo em vista que o fato de a tributação não ter seu conteúdo integralmente preenchido com clareza dá margem a um excesso de subjetivismo por parte do agente responsável pelo lançamento do imposto, uma vez que ele, discricionariamente, poderá se utilizar da lacuna existente para conceder privilégios indevidos. Além disso, aumentará a probabilidade de diferentes agentes administrativos aplicarem soluções distintas para contribuintes em situação similar, provocando, em ambos os casos, hipótese de violação à isonomia material.

Contudo, em que pese a necessidade de se evitar a utilização de critérios sem relação imediata com o bem imóvel, é preciso compreender que tal regra não é absoluta, motivo pelo qual deve comportar exceções. Esse entendimento adquire suma importância, na medida em que tal relativização representa uma forma de proporcionar aos contribuintes o efetivo respeito à sua capacidade de contribuir 
•• Tributação, direitos fundamentais e desenvolvimento

com as despesas do Estado, ainda que, para isso, haja uma ligeira distorção em conceitos tributários doutrinariamente definidos.

Com efeito, a fim de alcançar a máxima aplicação da capacidade contributiva no IPTU, mostra-se patente a necessidade de conjugar, simultaneamente, fatores inerentes ao bem imóvel tributado e também elementos de ordem externa.

Primeiramente, inevitável considerar que há circunstâncias capazes de transformar expressivamente o poder aquisitivo da população, reduzindo, por conseguinte, a possibilidade de arcar com todas as dívidas existentes, inclusive e sobretudo no que tange aos impostos, que, por se tratarem de prestações compulsórias, são débitos, cujas negociações de valores, não podem ocorrer por mera opção do contribuinte, tal como já foi apontado no presente trabalho. Registre-se que, inobstante tais elementos serem afetos à análise da renda global do sujeito passivo, e não meramente do seu patrimônio imobilizado, atingem frontalmente as dívidas decorrentes desse, que, de forma inevitável, serão adimplidas pela renda dinâmica manifestada.

De igual modo, importante ressaltar também a existência de outros critérios objetivos do bem tributado que, apesar de não afetarem diretamente o cálculo das respectivas bases de cálculo dos impostos, são capazes de auxiliar na análise do quantum de riqueza poderá ser extraída do patrimônio do contribuinte, por meio do IPTU e do ITR. Trata-se de hipótese excepcional, contudo, não pode ser ignorada, pois considerar como absoluta a premissa que determina que a elevação da base de cálculo desses impostos revela, necessariamente, uma maior capacidade de contribuir, pode criar diversas situaçóes de injustiça.

Diante disso, ao proceder com a fixação do quantum devido em dissonância com o entendimento ora esposado, estar-se-ia contribuindo para a criação de uma conjuntura que deve ser repelida do ordenamento jurídico pátrio, qual seja, a aceitação da injustiça fiscal, ainda que em casos excepcionais. Não se pode negar que tal situação ilustra uma hipótese de flagrante inconstitucionalidade, uma vez que viola comando emanado pelo Poder Constituinte originário que preceitua que a construção de uma sociedade justa deve ser um dos objetivos fundamentais da República Federativa do Brasil (vide art. $3^{\circ}$, inciso I da CRFB/88).

\subsection{Concretização da capacidade contributiva no ITR: imunidade e não incidência legalmente qualificada sobre as pequenas glebas}

A par da necessidade de a aplicação da capacidade contributiva ser maximizada com relação ao IPTU, conforme será analisada mais à frente, tal constatação 
não pode ser feita no que tange à cobrança tributária, através do ITR. Isso porque os contribuintes do ITR são beneficiados por duas hipóteses de não incidência qualificada que, ao mesmo tempo em que sinalizam sobre o uso de aspectos do bem imóvel envolvido, também preveem a utilização de requisitos relacionados ao proprietário do bem, o que acaba por refletir o inequívoco prestígio conferido pelo constituinte ao princípio da capacidade contributiva.

Sendo assim, antes de proceder à análise dos critérios capazes de tornar a tributação do IPTU mais justa, essencial tecer breves comentários atinentes às hipóteses de não incidência já aplicáveis na cobrança do ITR, pois, dessa forma, é possível corroborar o posicionamento aqui esposado no sentido de considerar plenamente compatível a máxima concretização da capacidade contributiva com os impostos de natureza real.

\subsubsection{Breves considerações sobre imunidade e hipótese de não incidência legalmente qualificada}

Conforme entendimento amplamente consagrado na doutrina, há dois grupos de hipóteses capazes de gerar consequências no ordenamento jurídico, quais sejam, as hipóteses de incidência e as hipóteses de não incidência. No primeiro caso, a concretização das hipóteses implicará a atração de uma norma apta a determinar a ocorrência de algum efeito jurídico sobre aquele fato concretizado. Noutro giro, o segundo grupo caracteriza hipóteses que, se forem exauridas - ou seja, transformadas em fatos concretos -, não ensejarão a aplicação de normas jurídicas, seja por mera ausência de previsão legal ou mesmo porque o legislador expressamente vedou a incidência de certas normas sobre algumas hipóteses.

Note-se que, trazendo tais considerações iniciais para o campo do Direito Tributário, é possível perceber sua especial relevância, haja vista que a criação e incidência de tributos devem estrita observância ao princípio da reserva legal, conforme apregoa o art. 150, inciso I, da CRFB/1988. Assim, é forçosa a compreensão de que as normas tributárias apenas poderão incidir sobre as hipóteses que a lei expressamente definir como passíveis de incidência. Nesse sentido, válido destacar lição de Luciano Amaro ${ }^{101}$ :

Diz-se que há incidência de tributo quando determinado fato, por enquadrar-se no modelo abstratamente previsto pela lei, se juridiciza e irradia o efeito, também legal-

101 AMARO, Luciano. Op. cit., p. 305. 
•• Tributação, direitos fundamentais e desenvolvimento

mente previsto, de dar nascimento a uma obrigação de recolher tributo. (...) Quando se fala de incidência (ou melhor, incidência de tributo), deve-se ter em conta, portanto, o campo ocupado pelos fatos que, por refletirem a hipótese de incidência do tributo legalmente definida, geram obrigações de recolher tributos (...).

No que tange às hipóteses de não incidência tributária, é possível dividi-las em dois grupos. $\mathrm{O}$ primeiro engloba hipóteses de não incidência denominadas pela doutrina de pura ou simples (ou não incidência tout $\operatorname{court}^{102}$ ), que são aquelas situaçôes que, se ocorridas, não atrairão normas de incidência simplesmente por ausência de previsão legal ("lacuna legislativa proposital"), ou seja, ao mesmo tempo em que não há autorização legal para a referida incidência, também não há qualquer vedação.

Por outro lado, no segundo grupo, há as hipóteses de não incidência qualificadas, abrangendo todas as hipóteses que não atraem incidência da norma tributária em razão de expressa vedação legal. Nesse caso, norma com conteúdo tributário expressamente restringe o Poder de Tributar do ente competente, impedindo que ele exercite sua competência em determinadas situações, seja motivado por decisões meramente políticas, seja objetivando a concretização de certos valores, tais como a proteção dos direitos e garantias individuais.

Nesse sentido, quando o comando vedatório advém de disposição infraconstitucional (constituiçôes estaduais, leis orgânicas dos municípios e do distrito federal, leis complementares nacionais de normas gerais ou leis instituidoras do tributo), ahipóteseserádenãoincidênciatributárialegalmenteouinfraconstitucionalmente qualificada. No entanto, quando a proibição decorre de um mandamento constitucional, estará caracterizado o instituto da hipótese de não incidência tributária constitucionalmente qualificada, que, segundo doutrina amplamente majoritária, poderá ser denominado simplesmente como imunidade tributária.

Registre-se que, em ambos os casos de não incidência qualificada, não haverá a ocorrência do fato gerador e, consequentemente, não ocorrerá também o surgimento da relação jurídica obrigacional tributária entre o ente tributante e o sujeito passivo, entretanto, apesar de tais similaridades, deve-se ressaltar que não há completa identidade entre esses institutos jurídicos.

Inegavelmente, a principal diferença entre essas hipóteses de não incidência guarda relação com a fonte legislativa da qual emanará o comando proibitivo e,

102 Ibidem, p. 306. 
sendo assim, considerando que a imunidade revela-se como um benefício fiscal gerado por força de norma com status constitucional, cabível a conclusão de que os demais traços distintivos entre os institutos serão decorrência lógica da posição de supremacia da CRFB/1988.

Válido salientar, ainda, que os benefícios fiscais ora em comento caracterizam-se como verdadeiras exceções no campo da arrecadação tributária, uma vez que irão de encontro à regra geral de que todos devem suportar os gastos gerais da coletividade, porquanto essas hipóteses de não incidência farão com que certo grupo de pessoas se liberte da incidência compulsória da norma criadora dos tributos ${ }^{103}$.

No entanto, considerando especialmente as imunidades, cabe esclarecer que, embora essas hipóteses acabem por refletir, de certa forma, um aparente privilégio, não se trata de benefício contrastante com o ordenamento jurídico pátrio, tendo em vista que sua utilização está pautada em fundamentos aptos a justificar o discrímen e, por conseguinte, consagrar a harmonia do sistema tributário. Apesar de não ser possível exigir que o constituinte tenha agido com coerência, quando da elaboração dos dispositivos integrantes da Carta Política brasileira, natural a presunção de que o seu trabalho não resultou em comandos dotados de arbitrariedade ${ }^{104}$.

É inegável reconhecer que parte das imunidades está fundamentada em decisões meramente políticas, bem como em razões de ordem técnica, nas quais o constituinte justificou a utilização do instituto para uniformizar o tratamento conferido por todos os entes em determinadas circunstâncias para, assim, manter a coerência de todo o ordenamento jurídico ${ }^{105}$.

No entanto, cabe salientar que a maior parte dessa espécie de benefícios fiscais tem como pilar fundamental a proteção de valores constitucionalmente relevantes, que acabará por conferir maior alcance a essas normas imunizantes, uma vez que o benefício gerado será decorrência natural da confluência de diversas normas, fazendo pressupor que a norma imunizante viria apenas para reforçar os enunciados constantes nos demais dispositivos constitucionais relacionados à garantia que se visa proteger ${ }^{106}$.

103 SHOUERI, Luís Eduardo. Op. cit., item 1.1 - capítulo IX.

104 Ibidem, item 1.2 - capítulo IX.

105 Ibidem, item 1.2 - capítulo IX.

106 Ibidem, p. item 1.2 - capítulo IX. 
-. Tributação, direitos fundamentais e desenvolvimento

Por outro lado, a proteção a esses valores fundamentais, muitas vezes, terá sua essencialidade elevada a um patamar tão superior, que poderá fazer com que a própria capacidade contributiva seja ignorada. Observe-se ${ }^{107}$ :

O fundamento das imunidades é a preservação de valores que a Constituição reputa relevantes (a atuação de certas entidades, a liberdade religiosa, o acesso à informação, a liberdade de expressão etc.), que faz com que se ignore a eventual (ou efetiva) capacidade econômica revelada pela pessoa (ou revelada na situação), proclamando-se, independentemente da existência dessa capacidade, a não tributabilidade das pessoas ou situações imunes. Yonne Dolácio de Oliveira registra 'o domínio de um verdadeiro esquema axiológico sobre o princípio da capacidade contributiva’. (grifo original)

Contudo, em que pese essa possível constatação, há imunidades que, diferentemente do disposto no enunciado supra, além de não desprezarem a capacidade contributiva do sujeito passivo, terão como objetivo precípuo assegurar a sua máxima consagração e a proteção de outros valores fundamentais, conforme se verá na hipótese a seguir analisada.

\subsubsection{As hipóteses de não incidência descritas no art. 153, $\S 4^{\circ}, 11, C R F B / 88$ e no art. $3^{\circ}$, II, da Lei 9.393/96}

A par das imunidades de impostos constantes no art. 150, inciso VI, da CRFB/1988, nas quais o ITR também é englobado, o constituinte previu outra hipótese de não incidência constitucionalmente qualificada específica para esse imposto no art. 153, $\$ 4^{\circ}$, inciso II. Tal dispositivo constitucional determina que a propriedade de imóveis, inseridos no conceito de pequena gleba, não atrairá a incidência da norma instituidora do ITR, contanto que o próprio proprietário promova a exploração do bem e não possua qualquer outro imóvel.

Nesse sentido, é possível reconhecer que os requisitos exigidos pelo artigo supracitado pertencem a três ordens distintas, que, entretanto, devem ser cumulativamente cumpridos. No que tange à limitação do tamanho do imóvel (pequenas glebas), trata-se de uma condicionante relacionada intrinsicamente ao bem; já em relação à necessidade de exploração da terra pelo proprietário, é possível vislumbrar que o constituinte prestigiou o aspecto econômico existente na relação entre o indivíduo e o bem de sua propriedade; e, por fim, ao limitar o número de imóveis, o

AMARO, Luciano. Op. cit., p. 174-175. 
constituinte confere especial relevância a uma condição relacionada ao proprietário do bem. Passa-se, portanto, à análise de cada um desses elementos.

Ao dispor sobre a necessidade de o imóvel ter suas dimensões enquadradas no conceito de pequena gleba, a norma imunizante demonstra que, para o seu conteúdo ser integralmente revelado, é imprescindível recorrer ao conteúdo de outra norma, que, dispondo sobre o significado de pequena gleba, será responsável por complementar o seu verdadeiro sentido. Tal incumbência ficou a cargo do parágrafo único do art. $2^{\circ}$ da Lei 9.393/96 (Lei instituidora do ITR) ${ }^{108}$, que, além de reiterar o conteúdo expresso na norma imunizante em comento, trata de fixar os limites territoriais correspondentes ao conceito de pequena gleba, in verbis:

Art. $2^{\circ}$ Nos termos do art. $153, \$ 4^{\circ}$, in fine, da Constituição, o imposto não incide sobre pequenas glebas rurais, quando as explore, só ou com sua família, o proprietário que não possua outro imóvel.

Parágrafo único. Para os efeitos deste artigo, pequenas glebas rurais são os imóveis com área igual ou inferior a:

I - 100 ha, se localizado em município compreendido na Amazônia Ocidental ou no Pantanal mato-grossense e sul-mato-grossense;

II - 50 ha, se localizado em município compreendido no Polígono das Secas ou na Amazônia Oriental;

III - 30 ha, se localizado em qualquer outro município.

Como é possível observar com a leitura do dispositivo supra, os critérios espaciais nele delimitados representam a tentativa de fixar os parâmetros aptos a caracterizar uma propriedade rural que, embora seja de dimensões módicas, possa ser efetivamente explorada por seu proprietário, o que incentiva a manutenção de terras produtivas e, consequentemente, inibe o surgimento de novos latifúndios improdutivos. Nesse sentido, parte-se para a análise do segundo requisito exigido para concessão da imunidade, qual seja, exploração das terras.

Conforme já mencionado, é requisito de ordem econômica, no entanto, é preciso salientar que sua relevância é elevada, em virtude de ser, notadamente, um elemento apto a representar a concretização do aspecto econômico da função social

108 BRASIL. Lei 9.393 de 19 de dezembro de 1996. Disponível em: <http://www.planalto.gov.br/ ccivil_03/Leis/L9393.htm>. Acesso em: 21 set. 2015. 
•• Tributação, direitos fundamentais e desenvolvimento

da propriedade, tal como apregoa o inciso I, do art. 186, da CRFB/1988 ${ }^{109}$, c/c com o caput do art. $6^{\circ}$ da Lei 8.629/1993 ${ }^{110}$.

Trata-se de uma exigência que objetiva fazer com que o proprietário promova o aproveitamento racional e adequado do solo, permitindo, com isso, que a propriedade ali situada concretize o direito fundamental à habitação dos que ali residem e, ao mesmo tempo, torne-se capaz de promover o sustento do proprietário e de sua família, seja com o aproveitamento de tudo aquilo que for cultivado, seja com a realização de pequenos negócios que auxiliem na aquisição de outros elementos necessários à sobrevivência.

Há que se notar, ainda, que, ao exigir que a exploração da terra seja feita pelo próprio proprietário, a norma imunizante ora analisada esclarece que um de seus objetivos é incentivar a criação de economias de subsistência, beneficiando, portanto, os detentores de pequenas terras que possuem a necessidade de prover seu sustento dos frutos gerados pelo próprio solo.

Por último, o constituinte exige que, para o proprietário se beneficiar da imunidade sobre as pequenas glebas, o imóvel seja o único de sua propriedade. Devido à clareza do enunciado imunizante, a princípio, não haveria motivação que justificasse dúvidas a respeito desse requisito. No entanto, surgiu o debate acerca da possibilidade de a imunidade se estender àqueles que, embora possuam dois ou mais imóveis, comprovem que a soma das dimensões desses bens não ultrapassa o conceito de pequena gleba.

Sendo assim, é inegável a constatação de que beneficiando tais proprietários, não se estaria diante de uma hipótese de injustiça fiscal, pois poderia haver situações que eles demonstrassem mais necessidade de usufruir desses benefícios do que aqueles detentores de um único imóvel. Contudo, estender a imunidade a eles ocasionaria ofensa ao comando constitucional imunizante, que, inequivocamente, restringiu a hipótese de não incidência aos que não possuíssem outros imóveis.

Diante desse impasse, a solução adveio de comando normativo do legislador ordinário, que, ao elaborar a redação do art. 3º, inciso II, da Lei 9.393/1996,

109 Art. 186 da CRFB/1988: A função social é cumprida quando a propriedade rural atende, simultaneamente, segundo critérios e graus de exigência estabelecidos em lei, aos seguintes requisitos: I - aproveitamento racional e adequado; (...)

110 Art. 6º caput da Lei n. 8.629/1993: Considera-se propriedade produtiva aquela que, explorada econômica e racionalmente, atinge, simultaneamente, graus de utilização da terra e de eficiência na exploração, segundo índices fixados pelo órgão federal competente. (...) 
definiu que a propriedade de um conjunto de imóveis rurais, cujas dimensões somadas não ultrapassassem os limites territoriais característicos da pequena gleba, não atrairia a incidência do ITR, ainda que tais bens pertencessem a um mesmo indivíduo. Assim, embora os proprietários que se encontram nessa situação não possam gozar da imunidade do ITR sobre pequenas glebas, a incidência desse imposto não ocorrerá sobre eles, por força da hipótese de não incidência legalmente/ infraconstitucionalmente qualificada constante no dispositivo supracitado - erroneamente denominado de isenção pelo legislador ordinário ${ }^{111}$.

Importante salientar, no entanto, que, na hipótese de o proprietário dos bens imóveis rurais, enquadrados no conceito de pequena gleba, deter um imóvel urbano, além de estar impedido de se beneficiar da imunidade em análise, também não poderá usufruir da hipótese de não incidência legalmente qualificada ora em comento, em razão de expressa vedação legal emanada de seu dispositivo regulamentador (vide art. 3º, inciso II, alínea 'b’, da Lei 9.393/1996).

Diante do exposto, analisando todos os requisitos essenciais à concessão dos benefícios fiscais supracitados, é inegável admitir que tanto o constituinte, quanto o legislador ordinário, optaram por utilizar, simultaneamente, elementos de ordem externa e interna do bem imóvel envolvido. Com isso, mostrou patente o prestígio conferido ao princípio da capacidade contributiva, porquanto, inegavelmente, ambas as hipóteses de não incidência procuraram beneficiar a parcela da população que teria seu sustento prejudicado, caso fosse exigido dela o pagamento do montante devido a título de ITR.

Note-se que, embora o princípio da capacidade contributiva tenha sido plenamente aplicado na tributação do ITR, não houve qualquer alteração na natureza

111 SCHOUERI, Luís Eduardo. Op. cit., item 5 - capítulo V. Conforme lição do autor, "Na sistemática adotada pelo Código Tributário Nacional, a isenção não se confunde com a não incidência, mas pressupõe a incidência. É por isso que a isenção é incluída, no art. 175 do Código Tributário Nacional, como hipótese de exclusão do crédito tributário. Ou seja: no modelo teórico ali inserido, o crédito tributário surge, mas o pagamento é dispensado, por conta da isenção. Assim é que a isenção está compreendida dentro do campo da incidência da norma, já que o legislador contemplou a hipótese (e por isso não seria caso de falar-se em não incidência), mas isentou o contribuinte do pagamento. A doutrina tradicional, apoiada nas lições de Rubens Gomes de Sousa, entende que haveria dois momentos cronologicamente não coincidentes: incidência da norma tributária num primeiro momento e incidência da norma isentiva num segundo, daí a conclusão de que 'a isenção pressupõe a incidência [da norma tributária], porque é claro que só se pode dispensar o pagamento de um tributo que seja efetivamente devido"”. 
•• Tributação, direitos fundamentais e desenvolvimento

real desse imposto, uma vez que as características do bem imóvel também foram consideradas. Com isso, é possível perceber a ratificação do entendimento, defendido no presente trabalho, no sentido de que tal princípio deve ser de observância obrigatória também nos impostos reais, sobretudo os que se relacionam diretamente com o direito à moradia dos cidadãos.

Nesse sentido, a concretização do princípio da capacidade contributiva também deve ser percebida quando da cobrança do IPTU, ainda mais considerando que tal imposto, além de atingir um número superior de contribuintes - se comparado ao ITR -, também é capaz de atingi-los com maior intensidade, afinal, como já visto, sua base de cálculo tende a representar um valor mais elevado. Frise-se que não se está a defender, necessariamente, a criação de outras hipóteses de não incidência, no entanto, independentemente da técnica legislativa escolhida, mostra-se de extrema importância considerar diferentes elementos para que, então, alcance-se uma tributação mais justa, conforme se verá adiante.

\subsection{A tributação por meio do IPTU e a concretização da capacidade contributiva: análise dos aspectos aptos a maximizar a consagração deste princípio}

\subsubsection{Desemprego}

Conforme conceituação disponibilizada pelo Instituto Brasileiro de Geografia e Estatística (IBGE) $)^{112}$, a taxa de desocupação ou de desemprego aberto define, numericamente, a parcela da população economicamente ativa - indivíduos com idade entre 10 e 65 anos de idade - que, embora esteja disponível para exercer funções laborais e tenha, de alguma forma, tentado se inserir no mercado de trabalho, não alcançou tal objetivo, mantendo-se, portanto, desocupada no período de referência da pesquisa.

Diante disso, pode-se compreender que aqueles que se encontram em situação de desocupação ou desemprego têm sua capacidade contributiva efetiva reduzida a zero, uma vez que, estando ausentes do mercado de trabalho, tais indivíduos não conseguirão obter recursos financeiros para arcar com as despesas necessárias a sua sobrevivência.

112 IBGE. Indicadores sociais minimos: conceitos. Disponível em: <http://www.ibge.gov.br/home/ estatistica/populacao/condicaodevida/indicadoresminimos/conceitos.shtm>. Acesso em: 27 set. 2015. 
Nesse sentido, tratando-se o desemprego de uma situação de inegável indisponibilidade de renda, necessário pressupor que a provisoriedade seria uma característica inerente a ele. Entretanto, é possível observar o enfraquecimento desse caráter provisório, uma vez que é cada vez maior o índice de desempregados que buscam por uma realocação no mercado de trabalho há um período superior a 1 ano, atingindo, em abril de 2014, 17,4\% do total de desempregados então existentes ${ }^{113}$.

Forçoso reconhecer que, inevitavelmente, o dever de pagar impostos também restará prejudicado, especialmente quando o contribuinte se deparar com a cobrança de impostos reais, como IPTU e ITR. Isso porque, diferentemente do que ocorre com os impostos pessoais - v.g. o Imposto de Renda -, o cálculo do montante devido a título de IPTU e ITR não sofre influência de fatores que promovem variações na renda dinâmica dos contribuintes.

Entretanto, sobretudo quando se está diante de uma situação de desemprego, concordar com o posicionamento anteriormente esposado, em última análise, implica admitir uma tributação inconstitucional por ofensa aos ditames da capacidade contributiva. Como já visto, a manifestação de riqueza tributável por IPTU é a propriedade, domínio útil ou posse com animus domini de imóvel urbano, e, sendo assim, presume-se que o contribuinte inserido em uma dessas hipóteses de incidência é capaz de adimplir com as obrigações tributárias decorrentes do imóvel.

Trata-se de uma presunção, a princípio, adequada, uma vez que, efetivamente, é esperado que aqueles capazes de adquirir um bem imóvel, também sejam capazes de mantê-lo. No entanto, não se pode tratar tal presunção como absoluta, havendo necessidade de se considerar também os aspectos imprevisíveis da vida em sociedade - como é o caso do desemprego - que, inevitavelmente, afetarão a possibilidade de cumprimento das obrigações tributárias.

Nesse sentido, o IPTU merece especial atenção, haja vista ser um imposto cujo inadimplemento poderá acarretar a perda do imóvel envolvido na referida relação jurídica obrigacional tributária. Ou seja, ao se deparar com a impossibilidade de pagamento do mencionado imposto, os contribuintes se verão obrigados a alienar seu imóvel para, então, adquirirem o montante necessário ao cumprimento da obrigação.

113 BRASILEIROS ficam mais tempo na fila do desemprego: tendência revela fraqueza da economia e antecede achatamento de salários, avaliam especialistas. Época Negócios, 25 de julho de 2014. Disponível em: <http://epocanegocios.globo.com/Informacao/Resultados/noticia/2014/07/ brasileiros-ficam-mais-tempo-na-fila-do-desemprego.html>. Acesso em: 11 set. 2015. 
-. Tributação, direitos fundamentais e desenvolvimento

Registre-se que tal alienação poderá ser feita espontaneamente pelo sujeito passivo, como meio de evitar a inscrição do débito em dívida ativa, ou, ainda, poderá ocorrer de forma coercitiva, pois, frise-se, o IPTU devido em função do imóvel é uma causa apta a excepcionar a impenhorabilidade do bem de família, como assevera o já citado art. $3^{\circ}$, inciso IV, da Lei 8.009/1990.

De qualquer forma, seja preventivamente ou no curso de execução fiscal, a alienação do bem imóvel indicará inevitável violação ao direito fundamental à moradia. Tal fato ocasionará, por conseguinte, o surgimento de um novo problema, qual seja, o de alojar as famílias que, em prol do adimplemento da obrigação tributária, tiveram que abdicar do direito a uma habitação. Assim, configurada está mais uma hipótese contraditória em que o Estado, por meio da cobrança desarrazoada e inadequada de IPTU, contribui de forma determinante para a violação dos direitos fundamentais que ele mesmo deveria garantir aos cidadãos.

Válido salientar, no entanto, que as reflexões feitas até aqui não representam argumentos em prol de um entendimento no sentido de que os desempregados deveriam se abster de pagar IPTU, uma vez que, dessa forma, o interesse público existente na arrecadação desse imposto restaria prejudicado. Contudo, defende-se que tal circunstância seja considerada, de modo a permitir uma cobrança mais adequada aos preceitos fundamentais da capacidade contributiva, recorrendo-se, por exemplo, à utilização da moratória.

A moratória está prevista no art. 151, inciso I, do CTN, como uma das hipóteses que geram a suspensão da exigibilidade do crédito tributário. Com a utilização desse instituto, observando-se os requisitos constantes nos artigos 152 e seguintes do mesmo diploma legal, é possível determinar a prorrogação do prazo para pagamento de tributos, em caráter geral ou individual, mediante a ocorrência de situações catastróficas que provocam notórias dificuldades financeiras. Sobre o tema, válido destacar a preciosa lição de Luiz Eduardo Shoueri ${ }^{114}$ :

Não se trata a moratória de criação recente do direito. Relata-se que já em Roma, no tempo de Constantino, podia o pretor ou o príncipe decidir pela concessão da moratória quando assim o exigissem as circunstâncias. Tal moratória atingia a generalidade dos credores, que ficavam, assim, impedidos de exigir o cumprimento das obrigações, desde que os devedores oferecessem garantias. Nota-se, daí, que a moratória protegia o devedor de um desastre financeiro, assegurando a sobrevivência do negócio. A moratória em matéria tributária era de uso frequente para os casos em que a

114 SHOUERI, Luís Eduardo. Op. cit., item 1 - capítulo XIV. 
colheita fosse insuficiente. No período do Império Romano, o Imperador declarava moratória e diferia a cobrança de impostos por alguns anos (...).

Ao conceder a moratória em caráter individual, o ente tributante permite que a suspensão de certo crédito tributário seja efetuada em favor de um grupo específico da população, que, comprovadamente, deverá cumprir os requisitos exigidos em lei. Dessa forma, não há dúvidas de que o referido benefício poderia ser concedido à parcela dos contribuintes que se encontra desempregada, pois trata-se de um grupo que, embora busque a reinserção do mercado de trabalho, não consegue se livrar da condição de indisponibilidade econômica.

Contudo, inobstante a análise ora efetuada, é necessário ressaltar que se trata de hipótese, cuja utilização merece cautela. O desemprego é uma circunstância que, apesar de influenciar na possibilidade de pagamento do IPTU, não guarda relação direta com as características do bem tributável.

Assim, com o objetivo de evitar a insegurança jurídica na tributação, bem como o desrespeito à natureza do referido imposto, essencial reconhecer a necessidade de considerar o desemprego como um critério que, somado a outros relacionados diretamente ao bem imóvel tributável - a seguir analisados -, será capaz de concretizar, de maneira mais efetiva, a capacidade contributiva no IPTU.

\subsubsection{Propriedade de um único imóvel}

Se por um lado é usualmente reconhecido que os detentores de bem imóvel demonstram ter aptidão para arcar com o pagamento do IPTU dele decorrente, forçoso reconhecer também que a quantidade de imóveis pertencentes a um mesmo contribuinte, inevitavelmente, revela a maior ou menor possibilidade de ele contribuir. Nesse sentido, pode-se compreender, de forma presumida, que a capacidade contributiva do sujeito passivo do IPTU é diretamente proporcional ao número de imóveis que ele detém.

Seguindo essa linha, o contribuinte de IPTU, proprietário de dois ou mais imóveis, não merece se beneficiar de uma atenuação do valor da cobrança do referido imposto, em razão de uma situação de desemprego, por exemplo. Nesse caso, o contribuinte não se encontraria em uma situação de completa indisponibilidade de renda, nem mesmo se veria diante de um risco iminente de perda do direito fundamental à moradia.

$\mathrm{Na}$ hipótese descrita anteriormente, ao se deparar com a cobrança de IPTU, o sujeito passivo, ainda que desempregado, teria a possibilidade de saldar o débito 
-• Tributação, direitos fundamentais e desenvolvimento

tributário com a utilização do outro bem, seja alienando-o ou transformando-o em fonte geradora renda - v.g. realizando a locação do bem. Desse modo, é possível constatar que, com o uso de um bem para manutenção de um outro, o contribuinte, ao mesmo tempo em que garante a manutenção do seu direito ao ambiente residencial, também permite a continuidade da sua participação frente às despesas públicas.

A contrario sensu, o detentor de apenas um bem imóvel não possui outros meios, senão a própria renda dinâmica, para arcar com o débito decorrente da cobrança de IPTU, demonstrando que, ausente essa espécie de renda, o pagamento do imposto restará prejudicado. Com isso, mostra-se adequado presumir a reduzida capacidade contributiva desses proprietários, sobretudo se comparados aos que possuem outros imóveis, que, de alguma forma, poderão utilizar os bens sobejantes para geração de renda, como anteriormente mencionado.

Diante do exposto, válido, então, proceder à análise do teor da súmula 589 do Supremo Tribunal Federal. O preceito dela emanado adverte sobre a impossibilidade de se fixar adicional progressivo em virtude da quantidade de imóveis do contribuinte, ou seja, trata-se de um enunciado que veda ao fisco municipal, quando da cobrança do IPTU, atingir os contribuintes com carga tributária mais intensa simplesmente em decorrência do fato de possuírem mais de um bem imóvel urbano.

Expor uma análise esmiuçada do teor da súmula em comento desviaria o foco do presente trabalho, contudo, forçoso reconhecer que o entendimento nela esposado acaba por permitir um favorecimento daqueles que, a princípio, seriam detentores de maior capacidade contributiva. No entanto, em que pese tal constatação, é possível compreender que o posicionamento ora esposado não viola frontalmente o entendimento jurisprudencial - ultrapassado - do Pretório Excelso sobre tema.

Em consonância com o que o STF preceitua neste verbete, os argumentos aqui apresentados não sugerem um endurecimento da carga tributária dos possuidores de patrimônio imobilizado mais valioso. Ao contrário, a defesa aqui apresentada é no sentido de revelar a necessidade de se gerar benefícios fiscais a certos contribuintes de IPTU que se encontram, ainda que transitoriamente, em situação de vulnerabilidade econômica, evitando-se, dessa forma, que futuras execuções fiscais ocasionem a perda de seu único imóvel.

Nesse sentido, a fim de corroborar a harmonia do critério exposto ao ordenamento jurídico pátrio, válido atentar-se para o conteúdo da súmula 539 do STF, in 
verbis ${ }^{115}$ : "É constitucional a lei do município que reduz o imposto predial urbano sobre imóvel ocupado pela residência do proprietário, que não possua outro”.

Diante da leitura dessa súmula, é possível depreender que seu conteúdo privilegia uma tributação segundo os ditames da capacidade contributiva, haja vista que permite a cada município diminuir o valor da cobrança em prol daqueles com capacidade reduzida para arcar com as despesas relacionadas ao IPTU.

No entanto, em que pese estar ratificada a constitucionalidade da referida redução de carga tributária, trata-se de uma medida cuja adoção representa uma faculdade conferida a cada município. Isso porque, considerando inexistir quaisquer mandamentos advindos de lei complementar capazes de limitar e uniformizar o modus operandi da cobrança do IPTU, os municípios, individualmente, teriam aptidão para definir a forma mais adequada de exercer a competência atribuída a eles pela CRFB/1988, desde que, obviamente, haja consonância com os valores protegidos por essa, tal como ocorre no caso em tela.

Embora a ausência de uniformização legislativa sobre o tema revele a desnecessidade de os municípios tributarem de acordo com a possibilidade indicada pela súmula 539 do STF - e que ora está sendo defendida -, é possível observar a existência de municípios seguindo a linha do posicionamento ora defendido, sendo válido destacar, exemplificativamente, a legislação tributária de Barra Mansa, município situado no interior do Estado do Rio de Janeiro. Conforme o dispositivo a seguir transcrito, tal município, por meio da Lei Complementar Municipal n. 57/2009 (Código Tributário Municipal de Barra Mansa), isenta contribuintes de IPTU que sejam proprietários de um único imóvel, in verbis ${ }^{116}$ :

Art. 30. São isentos do Imposto sobre a Propriedade Predial e Territorial Urbana:

(...)

IX - O proprietário de um único imóvel no Município, com no máximo 70 (setenta) metros quadrados de construção, desde que nele resida e que perceba até 3 (três) salários mínimos mensais, vigentes na região; (grifou-se)

Importante observar que, no trecho do dispositivo supra, não se trata de utilizar exclusivamente o critério ora exposto. Trata-se de uma hipótese de isenção

115 BRASIL. Códigos 3 em 1: Tributário; Processo Civil e Constituição Federal. 11. ed. São Paulo: Saraiva, 2015, p. 1036.

116 BARRA MANSA. Lei Complementar Municipal n. 57 de 21 de dezembro de 2009. Código Tributário Municipal. Disponível em: <http://prefeituradebarramansa.com.br/web/conteudo/downloads/LivroPrimeiro2402.pdf>. Acesso em: 20 set. 2015. 
•• Tributação, direitos fundamentais e desenvolvimento

tributária que combina a aplicação de quatro critérios distintos, que, se observados, ensejariam a concessão do referido benefício fiscal, a saber: restrições na quantidade de imóveis (um único imóvel), na renda percebida pelo contribuinte (máximo de três salários mínimos), no tamanho do bem (até setenta metros quadrados) e no seu uso (residência do proprietário).

Conforme insistentemente se expõe no presente trabalho, o objetivo fundamental deve ser a máxima concretização do princípio da capacidade contributiva na cobrança do IPTU, o que pode ser percebido na utilização conjunta de vários critérios, como fez o Município de Barra Mansa. Registre-se que a combinação de restrições ora defendida mostra-se muito importante para fortalecer a presunção de riqueza manifestada pelo contribuinte, permitindo-se, consequentemente, um tratamento fiscal mais adequado e isonômico.

\subsubsection{Delimitação do tamanho do imóvel associada ao respectivo valor venal}

É inegável constatar que restringir, exclusivamente, a quantidade de imóveis a fim de determinar os requisitos necessários para o contribuinte usufruir de benefícios fiscais, pode gerar situações de inequívoca injustiça fiscal. Note-se que o referido aspecto nem sempre revelará uma hipótese de fragilidade econômica do contribuinte, que poderá, por exemplo, ter uma única propriedade com um imóvel de amplas dimensões e destinado ao desenvolvimento de atividades comerciais com grande atuação no mercado nacional, o que, notavelmente, revela, a princípio, significativa capacidade de contribuir com os débitos tributários.

Diante disso, mostra-se necessário estabelecer outras restrições para que, então, seja possível observar o verdadeiro grau de essencialidade do imóvel para o sujeito passivo e, mais que isso, verificar a efetiva relação de dependência entre o exercício do direito à moradia do contribuinte e o imóvel a ser tributado. Nesse sentido, a delimitação no tamanho do imóvel e a restrição no uso do respectivo bem demonstram ser capazes de complementar os aspectos já analisados, permitindo, consequentemente, uma cobrança tributária mais justa.

A começar pela delimitação nas dimensões do bem tributável, trata-se de critério que permite criar uma presunção de que os proprietários de imóveis menores terão menor possibilidade de saldar débitos de IPTU e, assim, mereceriam gozar de benefícios fiscais a serem concedidos pelo município da localidade do bem. Dessa 
forma, a princípio, concedidos os benefícios a esses proprietários, estar-se-ia diante de uma situação de justiça fiscal.

No entanto, em que pese essa possível compreensão, é preciso considerar que, sobretudo em grandes cidades, o tamanho do imóvel tem adquirido cada vez menos importância para apuração da capacidade contributiva do sujeito passivo. Note-se, que, embora as dimensões do imóvel sejam um fator responsável por influenciar a fixação da base de cálculo do IPTU - valor venal do imóvel - em diversas hipóteses, a localização do bem tem sido um critério determinante para o referido cálculo, uma vez que se mostra capaz de elevar exponencialmente o seu valor, ainda que o bem tenha dimensões reduzidas e, a contrario sensu, diminuir seu valor, mesmo tratando-se de imóvel com grandes dimensões.

Com isso, é possível observar a possibilidade de contribuintes residentes em imóveis com grande extensão espelharem menor capacidade contributiva do que aqueles proprietários de bens com dimensões reduzidas. Sendo assim, considerar também o valor venal atribuído ao imóvel, adquire suma importância, pois, dessa forma, seria possível compatibilizar o binômio dimensões/localização e, consequentemente, possibilitar a melhor aferição do quanto seria razoável e adequado cobrar do sujeito passivo.

Nesse sentido, deve ser objeto de destaque a legislação do Município de Campinas, referente à cobrança de IPTU, tendo em vista que, através da Lei n. 11.111/2001 - após algumas alterações legislativas -, o referido município passou a conceder o benefício fiscal por ele denominado de "Isenção para habitação popular”. Tal benefício garante aos indivíduos proprietários de imóveis enquadrados nas dimensões e valores venais constantes no dispositivo regulamentador, a dispensa do pagamento do IPTU e, assim, contribui também para a melhor distribuição da carga tributária, dentre os contribuintes. A saber, válido a transcrição do art. 4\%, inciso III, alínea 'a' da supracitada Lei Municipal de Campinas n. 11.111/2001, com nova redação dada pela Lei Complementar Municipal n. 181/2017 ${ }^{117}$ :

Art. 4o São isentos do imposto:

(...)

III - os imóveis destinados a habitação popular nos seguintes casos: (nova redaçãa de acordo com a Lei Complementar n. 181, de 11/10/2017)

117 CAMPINAS. Lei Municipal n. 11.111 de 26 de dezembro de 2001. Disponível em: <https:// bibliotecajuridica.campinas.sp.gov.br/index/visualizaratualizada/id/126521>. Acesso em: 1 abr. 2018. 
-. Tributação, direitos fundamentais e desenvolvimento

a) cujos contribuintes possuam em seu patrimônio um único imóvel, situado no município, no qual efetivamente residam e que não ultrapasse os limites de área construída e valor venal relacionados nos itens 1 e 2 desta alínea: (nova redação de acordo com a Lei Complementar n. 181, de 11/10/2017)

1. cadastrado na categoria Residencial Horizontal $(\mathrm{RH})$ com área total construída não superior a $80,00 \mathrm{~m}^{2}$ (oitenta metros quadrados) ou na categoria Residencial Vertical (RV) com área total construída não superior a $50,00 \mathrm{~m}^{2}$ (cinquenta metros quadrados), sem área territorial excedente, cujo valor venal não ultrapasse 60.000 UFICs (sessenta mil Unidades Fiscais de Campinas) no mês de janeiro de cada exercício financeiro;

2. cadastrado na categoria Residencial Vertical (RV) com área construída de até $55,00 \mathrm{~m}^{2}$ (cinquenta e cinco metros quadrados) e que cumulativamente:

2.1. tenha valor venal, no mês de janeiro de cada exercício financeiro, de até 30.000 UFICs (trinta mil Unidades Fiscais de Campinas);

2.2. tenha o valor do metro quadrado do terreno tomado para cálculo do valor venal do imóvel de que trata o item 2.1 de até 150 UFICs $/ \mathrm{m}^{2}$ (cento e cinquenta Unidades Fiscais de Campinas por metro quadrado); (...)

\subsubsection{Uso residencial do imóvel}

Conforme aqui se expõe, todos os critérios, cuja utilização conjunta está sendo proposta no presente trabalho, revelam aptidão para proporcionar aos contribuintes do IPTU uma tributação de acordo com os ditames da justiça fiscal. Contudo, mostra-se imperiosa a constatação de que o critério atinente à forma de utilização do bem imóvel merece especial atenção, pois é esse o aspecto que poderá se relacionar mais diretamente com o direito fundamental à moradia dos contribuintes.

Os bens imóveis podem ser utilizados por seus proprietários de forma residencial ou não. Na primeira hipótese, o bem adquire singular importância na vida digna do contribuinte, pois sendo ele o local onde o sujeito passivo e, eventualmente, sua família, estabelecerão residência fixa, será através desse imóvel que o direito fundamental à moradia, previsto abstrata e genericamente no art. $6^{\circ}$, da CRFB/1988, será concretizado àquele determinado contribuinte.

Noutro giro, na hipótese de o sujeito passivo não utilizar o bem para fins de fixar a sua própria habitação, é possível concluir que, ainda que tal bem seja essencial ao seu sustento - v.g. uso do bem para prática de atividades empresariais - a relação firmada entre ele e o direito fundamental à moradia é meramente tangencial ou indireta, pois sendo o imóvel destinado a fins não residenciais, a concretização do direito fundamental à habitação se faria por outra maneira. 
Note-se que, quando o contribuinte utiliza o bem de sua propriedade para fixar a sua própria residência, surge uma relação de profunda dependência entre esse imóvel e o direito fundamental em comento, motivo pelo qual a oneração excessiva do bem acarretará, diretamente, a frustação do direito fundamental correspondente. Não por acaso, as legislações municipais tributárias colacionadas a título exemplificativo - Município de Barra Mansa, sul do Estado do Rio de Janeiro, e Município de Campinas, interior do Estado de São Paulo -, embora não prevejam isenções com idênticos requisitos, trataram de condicionar as respectivas hipóteses isentivas de IPTU à necessidade de o bem ser utilizado como residência do proprietário.

Ratificando esse entendimento ora esposado, válido ressaltar que, conforme já mencionado neste capítulo, o uso do bem imóvel é causa, prevista na Constituição Federal, que possibilita a diferenciação de alíquotas (art. 156, $\$ 1^{\circ}$, inciso II, CRFB/1988) pelos municípios instituidores do imposto em comento, o que, por sua vez, confirma a sua importância frente a uma cobrança tributária de acordo com os moldes da justiça fiscal e com demais valores protegidos pela Carta Política brasileira.

Diante do exposto, essencial depreender que, quanto maior e direta for a relação do bem imóvel com o direito fundamental à moradia de seu proprietário, maior deverá ser a preocupação em se adotar medidas razoáveis capazes de preservar a continuidade desse direito constitucionalmente garantido, ainda que, para isso, o ente municipal tenha que renunciar parte de sua arrecadação tributária. Não se trata de prevalência do interesse individual sobre o público, mas, ao contrário, pois, se é o próprio Estado Federal que deveria zelar pela preservação dos direitos fundamentais por ele garantidos aos cidadãos, onde estaria o interesse público se ele mesmo, sob a justificativa de manter a arrecadação dos tributos, contribuísse para a aniquilação desses direitos?

\section{CONCLUSÃO}

Diante do exposto, é possível constatar que arrecadar impostos é um poder-dever estatal essencial para a satisfação das despesas públicas geradas e, consequentemente, para manutenção de toda a coletividade. No entanto, inobstante isso, não se pode considerá-lo como um poder-dever a ser exercido de qualquer forma, sendo imprescindível, ao contrário, a observância de certos limites, que, por sua 
•• Tributação, direitos fundamentais e desenvolvimento

vez, impedirão que o Estado tribute os que não revelem qualquer signo presuntivo de riqueza ou absorva toda a riqueza manifestada pelos contribuintes.

Dessa forma, a capacidade contributiva surgiu como o principal limitador à atuação estatal quando da cobrança tributária, uma vez que, integrada ao texto constitucional (art. 145, $\$ 1^{\circ}$ da CRFB/1988), impõe aos entes que, "sempre que possível", os impostos sejam graduados em conformidade com a capacidade econômica dos indivíduos. Ora, trata-se de uma garantia que requer sua máxima concretização para ser cumprida, sob pena de a cobrança tributária figurar como inconstitucional.

Nesse sentido, não há cabimento em excluir da abrangência do referido mandamento constitucional, a tributação incidente sobre o patrimônio, sobretudo os impostos que se relacionam diretamente aos bens destinados à moradia dos contribuintes, caso do IPTU e do ITR. A cobrança desses impostos, que possuem natureza real, deve, inevitavelmente, guardar relação com as características do imóvel envolvido, contudo, se a fixação do valor a ser cobrado ficar restrita a esses fatores, tratar-se-ia de uma hipótese de injustiça fiscal. Afinal, ao considerar que a manutenção do patrimônio imobilizado do contribuinte tem sua gênese na renda dinâmica dele, forçoso reconhecer que a pessoa do contribuinte sempre será atingida.

Sendo assim, ainda que o agente responsável pelo lançamento considere as características do imóvel a ser tributado, devem ser considerados, conjuntamente, outros aspectos que, embora não se relacionem diretamente com a coisa, influenciam, significativamente, na possibilidade de o sujeito passivo da relação tributária arcar com as despesas e, mais que isso, refletem de forma mais satisfatória a capacidade contributiva do sujeito.

Conforme visto, o que fora esposado no presente trabalho representa um posicionamento plenamente compatível com o Ordenamento Jurídico pátrio, o que pôde ser comprovado com a análise das hipóteses de não incidência tributária (vide art. $153, \$ 4^{\circ}$, inciso II da CRFB/1988 e art. 30 , inciso II da Lei 9.393/1996) relativas ao ITR. Tais hipóteses demonstram a completa adequação entre uma tributação de impostos incidentes sobre o patrimônio e a aplicação de critérios imediatamente relacionados ao bem imóvel envolvido e, ao mesmo tempo, fatores aptos a demonstrar a essencialidade dele para o respectivo proprietário exercer o seu direito fundamental à moradia. 
Aplicar à cobrança do IPTU a mesma lógica - ainda que por meio de outros instrumentos - é de suma importância para que nesse imposto possa haver a plena justiça fiscal. Registre-se que, tal como proposto, considerar a situação de desemprego do contribuinte, o número de imóveis de sua propriedade, as dimensões do bem, assim como o seu uso residencial, adquire especial importância para aferir a efetiva capacidade contributiva dos indivíduos, pois ora esses fatores representarão a completa indisponibilidade de renda para arcar com os débitos, ora demonstrarão o alto grau de essencialidade do bem para a sobrevivência do contribuinte e de sua família.

Com isso, fazer com que o Estado - mais especificamente os municípios, competentes para instituição do IPTU - impute aos seus administrados uma cobrança plenamente de acordo com os moldes da capacidade contributiva é essencial, sobretudo nesse imposto intimamente relacionado com o direito à moradia dos proprietários e cuja inadimplência poderá ocasionar a perda do bem único do contribuinte e, por conseguinte, a extinção do direito fundamental a ele correspondente. Necessário perceber que, agindo dessa forma, o Estado não atenderá meramente os interesses particulares de cada contribuinte beneficiado por uma tributação mais adequada, mas, principalmente, atuará em prol na concretização de um dos objetivos fundamentais da República Federativa do Brasil, qual seja, a construção de uma sociedade livre, justa e solidária.

\section{REFERÊNCIAS}

AMARO, Luciano. Direito tributário brasileiro. 17. ed. São Paulo: Saraiva, 2011.

ÁVILA, Humberto. Teoria da igualdade tributária. 2. ed. São Paulo: Malheiros, 2009.

BARRA MANSA. Lei Complementar Municipal n. 57 de 21 de dezembro de 2009. Código Tributário Municipal. Disponível em: <http://prefeituradebarramansa.com.br/ web/conteudo/downloads/LivroPrimeiro2402.pdf>. Acesso em: 20 set. 2015.

BONOMO, Carla. A eficácia da capacidade contributiva e a justiça social. Revista do Direito Público (Londrina), v. 4, p. 29-42, maio/ago.2009. Disponível em: <http://www. uel.br/revistas/uel/index.php/direitopub/index>. Acesso em: 24 ago. 2014.

BRASIL. Códigos 3 em 1: Tributário, Processo Civil e Constituição Federal. 11. ed. São Paulo: Saraiva, 2015. 1067p.

BRASIL. Constituição da República Federativa do Brasil. Constituição (1988). Brasília, Distrito Federal: Senado, 1988.

BRASIL. Lei 5.172 de 25 de outubro de 1966 (Código Tributário Nacional). Código Tributário Nacional. Brasília, Distrito Federal: Senado, 2002. Disponível em: <http:// www.planalto.gov.br/ccivil_03/leis/15172.htm>. Acesso em: 5 set. 2014. 
•• Tributação, direitos fundamentais e desenvolvimento

BRASIL. Lei 8.629 de 25 de fevereiro de 1993. Dispóe sobre a regulamentação dos dispositivos constitucionais relativos à reforma agrária, previstos no Capítulo III, Título VII, da Constituição Federal. Brasília, Distrito Federal: Senado, 1996. Disponível em: <http://www.planalto.gov.br/ccivil_03/LEIS/L8629.htm>. Acesso em: 20 de agosto de 2015.

BRASIL. Lei 9.393 de 19 de dezembro de 1996. Disponível em: <http://www.planalto. gov.br/ccivil_03/Leis/L9393.htm>. Acesso em: 21 set. 2015.

BRASIL. Poder Legislativo. Comissão de Constituição e Justiça e de Redação. Diário do Senado Federal, Brasília, DF, 19.06.1996. p. 10244-10245. Disponível em: <http://www. stf.jus.br/arquivo/biblioteca/pec/EmendasConstitucionais/EC26/Senado/EC026_ sen_18061996_ini.pdf>. Acesso em: 11 out. 2014.

BRASIL. Supremo Tribunal Federal. IPTU. Progressividade. Recurso Extraordinário n. 153.771/MG. Relator Ministro Carlos Velloso. Brasília, 20 de novembro de 1996. Disponível em: <http://www.stf.jus.br/portal/jurisprudencia/listarJurisprudencia.asp?s1=IPTU+progr essivo\%28153771.NUME.+OU+153771.ACMS.\%29\&base=baseAcordaos $>$. Acesso em: 14 ago. 2015.

BRASIL. Supremo Tribunal Federal. IPTU. Progressividade. Recurso Extraordinário n. 586.693/ SP. Relator Ministro Marco Aurélio. Brasília, DF, 09 de dezembro de 2008. Disponível em: <http://www.stf.jus.br/portal/processo/verProcessoAndamento.asp?incidente=2617543>. Acesso em: 20 set. 2015.

BRASIL. Supremo Tribunal Federal. IPTU. Progressividade. Recurso Extraordinário n. 423.768/SP. Relator Ministro Marco Aurélio. Brasília, DF, 01 de dezembro de 2010. Disponível em: <http://www.stf.jus.br/portal/processo/verProcessoAndamento. asp? incidente $=2219868>$. Acesso em: 20 set. 2015.

BRASIL. Supremo Tribunal Federal. Recurso Extraordinário n. 632.795/MG. Relator Ministro Dias Toffoli. Brasília, DF, 07 de novembro de 2011. DJe 14.11.2011. Disponível em: <http://stf.jusbrasil.com.br/jurisprudencia/22876134/recurso-extraordinario-re632795-mg-stf $>$. Acesso em: 22 set. 2015.

BRASIL. Supremo Tribunal Federal. Recurso extraordinário. Constitucional. Tributário. Lei estadual: progressividade de alíquota de imposto sobre transmissão causa mortis e doação de bens e direitos. Constitucionalidade. Art. 145, $\$ 1^{\circ}$, da constituição da república. Princípio da igualdade material tributária. Observância da capacidade contributiva. Recurso extraordinário provido. Recurso Extraordinário n. 562045/RS. Relator Ministro. Ricardo Lewandowski. Brasília, DF, 06 de fevereiro de 2013, Tribunal Pleno, DJe 27.11.2013 EMENT VOL-02712-01 PP-00001. Disponível em: <http://www.stf.jus.br/ portal/jurisprudencia/listarJurisprudencia.asp?s1=\%28RE $\% 24 \% 2 \mathrm{ESCLA} \% 2 \mathrm{E}+\mathrm{E}+562$ 045\%2ENUME $\% 2 \mathrm{E} \% 29+\mathrm{OU}+\% 28 \mathrm{RE} \% 2 \mathrm{EACMS} \% 2 \mathrm{E}+\mathrm{ADJ} 2+562045 \% 2 \mathrm{EACMS}$ $\% 2 \mathrm{E} \% 29 \&$ base=baseAcordaos\&url=http://tinyurl.com/acyfaah>. Acesso em: 23 set. 2015. 
A aplicação do princípio da capacidade contributiva na tributação...

BRASILEIROS ficam mais tempo na fila do desemprego: tendência revela fraqueza da economia e antecede achatamento de salários, avaliam especialistas. Época Negócios, 25 de julho de 2014. Disponível em: <http://epocanegocios.globo.com/Informacao/Resultados/ noticia/2014/07/brasileiros-ficam-mais-tempo-na-fila-do-desemprego.html>. Acesso em: 11 set. 2015.

CAMPINAS. Lei Municipal n. 11.111 de 26 de dezembro de 2001. Disponível em: <https://bibliotecajuridica.campinas.sp.gov.br/index/visualizaratualizada/id/126521>. Acesso em: 1 abr. 2018.

COÊLHO, Sacha Calmon Navarro. Curso de direito tributário brasileiro. 7. ed. Rio de Janeiro: Forense, 2004.

COSTA, Regina Helena. Princípio da capacidade contributiva. 4. ed. São Paulo: Malheiros, 2012.

CARLI, Ana Alice de. Bem de família do fiador e o direito humano fundamental à moradia. Rio de Janeiro: Lumen Juris, 2009.

DIAS, Daniella S. O direito à moradia digna e a eficácia dos direitos. Revista Eletrônica do CEAF, n. 1, p. 1-15, out. 2011/jan. 2012. Disponível em: <http:/www.mprs.mp.br/ areas/biblioteca/arquivos/revista/edicao_01/vol1nolart1.pdf>. Acesso em: 24 ago. 2014.

FERREIRA, Abel Henrique. O princípio da capacidade contributiva frente aos tributos vinculados e aos impostos reais e indiretos. Fórum de Direito Tributário, v. 6, p. 71-105, 2003.

GONÇALVES, Carlos Roberto. Direito civil brasileiro. 11. ed. São Paulo: Saraiva, 2014. v. 2: Teoria geral das obrigações (e-book).

GRECO, Marco Aurélio. IPTU - Progressividade - Função social da propriedade. Revista de Direito Tributário, São Paulo: RT, n. 52, p. 110-121, abr./jun. 1990.

GRUPENMACHER, Betina Treiger. IPTU, ITBI e capacidade contributiva: diversidade de bases de cálculo e critérios para a progressividade. Instituto Brasileiro de Estudos Tributários. Disponível em: <http://www.ibet.com.br/download/Betina\%20Treiger\%20 Grupenmacher(2).pdf>. Acesso em: 23 ago. 2014.

HARADA, Kiyoshi. Valor venal. Prevalência do conceito legal. Disponível em: <http:// www.ambito-juridico.com.br/site/index.php?n_link=revista_artigos_leitura\&artigo_ id=2839>. Acesso em: 19 jul. 2015.

IBGE. Indicadores sociais mínimos: conceitos. Disponível em: <http://www.ibge.gov.br/ home/estatistica/populacao/condicaodevida/indicadoresminimos/conceitos.shtm >. Acesso em: 27 set. 2015.

IBGE. PNAD - Contínua mostra desocupação de 8,3\% no $2^{\circ}$ tri de 2015. Disponível em: $<$ http://saladeimprensa.ibge.gov.br/noticias? view=noticia \&id=1\&idnoticia=2968 \&busc 
•• Tributação, direitos fundamentais e desenvolvimento

$\mathrm{a}=1 \& \mathrm{t}=$ pnad-continua-mostra-desocupacao-8-3-2\%C2\%BA-tri-2015>. Acesso em: 11 set. 2015 .

MACHADO, Hugo de Brito. Tributo com efeito de confisco. Revista Dialética de Direito Tributário, Rio de Janeiro, n. 166, p. 93-113, jul. 2009.

MELO, José Eduardo Soares de. Dicionário de direito tributário: material e processual. São Paulo: Saraiva, ISBN 978-85-02-17295-1, 2012 (e-book).

MOTTA, Marianna Martini. Do poder de tributar ao dever fundamental de pagar impostos: a via da efetivação dos direitos sociais. Disponível em: <http://www.ambito-juridico.com. br/site/index.php?n_link=revista_artigos_leitura\&artigo_id=2252> Acesso em: 24 jan. 2015 .

NOGUEIRA, André Murilo Parente; ROSSO, Maria Izabel Souza. O Estado fiscal e o poder de tributar. Revista Jurídica da Presidência da República, Brasília, v. 9, n. 84, p. 195207, abr./maio 2007. Disponível em: <http://www.planalto.gov.br/ccivil_03/revista/ Rev_84/Artigos/PDF/AndreMurilo_rev84.pdf>. Acesso em: 20 jan. 2015.

OLIVEIRA, Yonne Donácio de. Progressividade do IPTU e princípios da capacidade contributiva e da redistribuição. Cadernos de Direito Tributário de Finanças Públicas, São Paulo: RT, n. 17, p. 40-45, out./dez. 1996.

PAOLIELLO, Patrícia Brandão. O princípio da capacidade contributiva. Disponível em: <http://jus.com.br/artigos/4138/o-principio-da-capacidade-contributiva>. Acesso em: 6 jan. 2015.

PASQUALON, Maicon Girardi. A aplicabilidade de alíquotas progressivas ao ITCMD sob a luz do principio da capacidade contributiva. Disponível em: <http://jus.com.br/ artigos/37513/a-aplicabilidade-de-aliquotas-progressivas-ao-itcmd-sob-a-luz-doprincipio-da-capacidade-contributiva>. Acesso em: 29 ago. 2015.

PAULSEN, Leandro. Impostos federais, estaduais e municipais. 7. ed. rev. e atual. Porto Alegre: Livraria do Advogado, ISBN 978-85-7348-786-2, 2012 (e-book).

PISANI, Carolina Dorneles. O principio da capacidade contributiva e os limites ao poder de tributar: um caminho à concretização da justiça fiscal. Disponível em: <http://www. anfip.org.br/publicacoes/20120726211721_Carolina-Dorneles-Pisani-II-Concurso-deMonografias-1-Lugar_28-04-2011_monografia_carolina_dorneles_pisani_2011.pdf>. Acesso em: 6 set. 2014.

PROCHALSKI, Daniel. Solidariedade social e tributação. Disponível em: <http://sisnet. aduaneiras.com.br/lex/doutrinas/arquivos/270607a.pdf>. Acesso em: 24 jan. 2015.

ROSSO, Paulo Sérgio. Tributação e Solidariedade no Estado brasileiro. Revista Eletrônica da OAB. Disponível em: <http://www.oab.org.br/editora/revista/revista_07/anexos/ tributacao_e_solidariedade.pdf>. Acesso em: 25 jan. 2015. 
SCHOUERI, Luís Eduardo. Direito tributário. 2. ed. São Paulo: Saraiva, 2012, ISBN 978-85-02-16120-7, (e-book).

SILVA, José Afonso da. Comentário contextual à Constituição. 8. ed. São Paulo: Malheiros, 2012.

TIPKE, Klaus; YAMASHITA, Douglas. Justiça fiscal e o princípio da capacidade contributiva. São Paulo: Malheiros, 2002.

VALADÃO, Alexsander Roberto Alves. O minimo existencial e as espécies tributárias. Curitiba, 2008. 347 f. Tese (Doutorado em Direito) - Universidade Federal do Paraná, 2008. Disponível em: <http://dspace.c3sl.ufpr.br:8080/dspace/bitstream/handle/ $1884 / 18288 /$ Alexsander $\% 20$ Roberto\%20Alves\%20Valadao\%20\%28tese\%29. pdf? sequence $=1>$. Acesso em: 6 set. 2014 .

VESQUES, Sérgio. Capacidade Contributiva, Rendimento e Património. Revista Fórum de Direito Tributário - RFDT, Belo Horizonte, n. 11, p. 23-61, set./out. 2004. Disponível em: <http://www.sergiovasques.com/xms/files/Capacidade_Contributiva_Rendimento. pdf> Acesso em: 23 de agosto de 2014. 
